\title{
So depression is an inflammatory disease, but where does the inflammation come from?
}

\author{
Michael Berk ${ }^{1,2,3,4^{*}}$, Lana J Williams ${ }^{1,2}$, Felice N Jacka ${ }^{1,2}$, Adrienne O'Neil ${ }^{1,5}$, Julie A Pasco ${ }^{1,6}$, Steven Moylan ${ }^{1}$, \\ Nicholas B Allen ${ }^{7}$, Amanda L Stuart ${ }^{1}$, Amie C Hayley' ${ }^{1}$, Michelle L Byrne ${ }^{7}$ and Michael Maes ${ }^{1,8}$
}

\begin{abstract}
Background: We now know that depression is associated with a chronic, low-grade inflammatory response and activation of cell-mediated immunity, as well as activation of the compensatory anti-inflammatory reflex system. It is similarly accompanied by increased oxidative and nitrosative stress (O\&NS), which contribute to neuroprogression in the disorder. The obvious question this poses is 'what is the source of this chronic low-grade inflammation?'

Discussion: This review explores the role of inflammation and oxidative and nitrosative stress as possible mediators of known environmental risk factors in depression, and discusses potential implications of these findings. A range of factors appear to increase the risk for the development of depression, and seem to be associated with systemic inflammation; these include psychosocial stressors, poor diet, physical inactivity, obesity, smoking, altered gut permeability, atopy, dental cares, sleep and vitamin D deficiency.

Summary: The identification of known sources of inflammation provides support for inflammation as a mediating pathway to both risk and neuroprogression in depression. Critically, most of these factors are plastic, and potentially amenable to therapeutic and preventative interventions. Most, but not all, of the above mentioned sources of inflammation may play a role in other psychiatric disorders, such as bipolar disorder, schizophrenia, autism and post-traumatic stress disorder.
\end{abstract}

Keywords: Depression, Inflammation, Cytokines, Diet, Obesity, Exercise, Smoking, Vitamin D, Dental cares, Sleep, Atopic, Gut, Oxidative stress

\section{Background}

There is now an extensive body of data showing that depression is associated with both a chronic low-grade inflammatory response, activation of cell-mediated immunity and activation of the compensatory antiinflammatory reflex system (CIRS), characterized by negative immunoregulatory processes $[1,2]$. New evidence shows that clinical depression is accompanied by increased oxidative and nitrosative stress (O\&NS) and autoimmune responses directed against O\&NS modified neoepitopes $[3,4]$.

Not only is depression present in acute illness [4,5], but higher levels of inflammation appear to increase the risk for the development of de novo depression [6].

\footnotetext{
* Correspondence: mikebe@barwonhealth.org.au

${ }^{1}$ IMPACT Strategic Research Centre, School of Medicine, Deakin University, Geelong, VIC, Australia

2Department of Psychiatry, University of Melbourne, Parkville, VIC, Australia Full list of author information is available at the end of the article
}

Indeed, cytokines induce depressive-like behaviors; in studies where healthy participants are given endotoxin infusions to trigger cytokines release, classical depressive symptoms emerge [7]. Exogenous cytokine infusions also cause the classical phenotypic behavioral and cognitive features of depression. As an exemplar, a quarter of the people given interferon for the treatment of hepatitis $\mathrm{C}$ develop emergent major depression [8,9]. Intriguingly, antidepressants, particularly selective serotonin reuptake inhibitors (SSRIs), in vitro or ex vivo exert significant negative immunoregulatory effects, decreasing the production of pro-inflammatory cytokines, for example, tumor necrosis factor (TNF) $\alpha$ and interleukin (IL)-1, $\mathrm{T}$ cell cytokines, for example, interferon (IFN)y, and increasing that of anti-inflammatory cytokines, for example, IL-10 $[10,11]$. They additionally alter leucocyte mRNA gene expression of some immune markers. Galecki first documented altered expression of mRNA coding for cyclooxygenase-2, myeloperoxidase, inducible

\section{Ciomed Central}


nitric oxide synthase and secretory phospholipase A2 type IIA in people with recurrent depressive disorder [12]. Additionally, inflammatory gene expression secondary to antidepressant therapy has been examined, with lowered levels of IL-1 $\beta$ and macrophage inhibiting factors seen after treatment, changes which were not associated with treatment response. However, lowering of IL-6 levels was associated with antidepressant response [13].

However, clinical depression is accompanied by a "resistance" to these ex vivo or in vitro effects of antidepressants attenuating inflammation and $\mathrm{T}$ cell activation [14]. Moreover, remission of clinical depression is accompanied by a normalization of inflammatory markers [15], while lack of response is associated with persistently elevated levels of inflammatory markers [16]. This resistance to the immunosuppressive effects of antidepressants in depressed patients may be explained by chronic inflammatory processes, chronic damage by O\&NS and the onset of autoimmune responses [14].

These data beg the question: what are the sources of this chronic low-grade inflammatory and O\&NS process and the source of the resistance to the well documented immunosuppressive effects of antidepressants? Any processes that activate chronic inflammatory and cellmediated processes without a concomitant activation of the CIRS may further aggravate the detrimental effects of activated immuno-inflammatory pathways. It is wellknown that many inflammatory disorders (chronic obstructive pulmonary disease, cardiovascular disease (CVD) and autoimmune disorders) and neuroinflammatory disorders (multiple sclerosis and Parkinson's disorder) and inflammatory conditions (hemodialysis and the postpartum period) may trigger clinical depression [17]. However, these factors are only present in a small percentage of the larger population of depressed individuals. In contrast, there are a variety of widely prevalent environmental factors that are associated with increased risk for the development of depression. The aim of this review was, therefore, to collate extant data on the role of inflammation and O\&NS as possible mediators of known environmental risk factors in depression, and to discuss potential implications of these findings, acknowledging the exploratory nature of these relationships. This paper will discuss those salient environmental variables that are risk factors for depression and examine immune dysregulation as a potential mediator of the interaction. This relationship has the potential to suggest both novel therapeutic and preventative approaches.

\section{Stress and trauma}

Of all the factors in this review, stressors and trauma have attracted the greatest extant literature. Psychosocial stressors, including acute psychological trauma or more sub-chronic stressors, and early exposure to childhood trauma robustly increase the risk of developing clinical depression and mood symptoms, while impacting neuroimmune circuits. There is now evidence that in experimental animals, different types of psychosocial stressors increase systemic and CNS levels of pro-inflammatory cytokines, including IL-1 and IL-6. For example, immobilization stress, mild inescapable foot shock, chronic mild stress, tail restraint stress, and social isolation in rodent models cause significant increases in IL-1 (mRNA) levels in the plasma and brain [18-23]. Moreover, the onset of depressive-like behaviors following external stressors (for example, learned helplessness and chronic mild stress) is associated with activated transcriptional factors (for example, nuclear factor $\mathrm{\kappa B}$ ), activation of other inflammatory pathways (for example, cyclooxygenase 2 and prostaglandin production), and increased apoptosis (for example, lowered levels of Bcl-2 and Bcl-2-associated athanogene 1) [24].

In humans, there is evidence that different types of psychosocial stressors may stimulate the pro-inflammatory cytokine network, including increases in IL-6 and TNFo [25-28]. Maes et al. [28,29] were the first to report that stress-induced increases in IFN $\gamma$ and stress-induced Th1 dominance were significantly correlated with stressinduced anxiety and distress. Thus, subjects with psychological stress-induced distress and anxiety showed significantly greater increases in IFN $\gamma$ and lower IL-10 than those without distress and anxiety. Psychosocial stress is also accompanied by lowered levels of endogenous, anti-inflammatory compounds, for example, CC16 (uteroglobuline), which decreases the production of IFNY [30]. Individuals showing stress-induced decreases in CC16 in the serum display higher stressinduced anxiety and distress, and an increased production of IFNY during the stress condition $[29,30]$. Thus, stress-induced increases in pro-inflammatory and Th1like cytokines may be mediated by lowered levels of endogenous anti-inflammatory compounds, such as CC16. Stress-induced production of pro-inflammatory cytokines, for example, TNF $\alpha$ and IL-6, and Th1-like cytokines, for example, IFN $\gamma$, are related to an increased number of leukocytes and neutrophils, and expression of immune cell activation markers, including $\mathrm{CD} 2{ }^{+} \mathrm{CD} 26^{+}$ and $C D 2^{+} H L A D R$, and different signs of an acute phase response [29]. This indicates that psychosocial stressinduced elevations in pro-inflammatory cytokines orchestrate stress-induced changes in peripheral blood immune cells, inflammatory reactions and neurobehavioral changes.

The findings that psychosocial stressors modulate the production of pro-inflammatory versus anti-inflammatory or negative immunoregulatory cytokines has important implications for stress-related disorders, including 
depression and post-traumatic stress disorder (PTSD). Thus, psychosocial stressors, such as negative life events, and chronic psychosocial stress often precede the onset of clinical depression. Translational models show that pro-inflammatory cytokines, such as IL-1 $\beta$, IL-6 and TNF $\alpha$, are depressogenic and anxiogenic. These mechanisms may explain why psychosocial stressors and acute psychotrauma may trigger mood disorders in vulnerable subjects, for example, those with immune gene polymorphisms, lowered levels of pepdidases, including dipeptidylpeptidase and prolylendopeptidase, and those with increased inflammatory burden [31].

Evidence from animal models has long suggested that early exposure to trauma in childhood may increase the subsequent risk of poor functioning of the immune, endocrine and nervous systems. More recently, studies conducted with humans have corroborated these findings. Data from the Dunedin Multidisciplinary Health and Development Study in New Zealand, a longitudinal study following 1,000 participants from birth to 32 years, have demonstrated that individuals experiencing stress in childhood resulting from maltreatment, abuse, social isolation and economic hardship are twice as likely to suffer chronic inflammation [32]. The detrimental impact of adversity on health in adulthood has also been demonstrated in US populations. Kiecolt-Glaser [33] found that childhood adversity can shorten the lifespan by 7 to 15 years, arguing that stress associated with abuse, death of a parent or parental relationship problems can lead to inflammation and premature cell aging, when compared with individuals who have not experienced such adversity. Miller et al. [34], in a further study focusing on depression outcomes, compared C-Reactive Protein (CRP) and IL-6 levels of women with and without history of childhood adversity; the former group was shown to have a greater likelihood of depression, recording higher levels of inflammation using these biomarkers. Studies exploring the influence of stress on other inflammatory diseases, such as CVD [35] and metabolic syndrome [36], have consistently shown similar trends. Such findings highlight the fundamental idea that stress occurring early in life can exert persistent effects over long periods of time, not only increasing susceptibility to somatic and psychiatric illness, but potentially interfering with treatment response.

However, the association between childhood adversity and vulnerability to inflammatory disease cannot fully be explained by a prolonged period of stress initiated by such an event. Rather, it is possible that learned, maladaptive responses to stress occurring in early childhood are also employed later in adult life in response to stressors. Thus, stress in adulthood has become of increasing interest as an instrumental risk factor for disease onset. For example, there is evidence that personality and the way in which an individual responds to psychosocial stressors, such as examination stress or job strain, may contribute to inflammatory processes [37]. Slavich et al. [38] found that responses to social stress via neural activity lead to marked increases in inflammatory activity. Similarly, Emeny [39] found job strain to have a direct effect on inflammation, and to influence other risk factors for inflammation. Job strain is known as a risk factor for other inflammatory diseases, such as CVD, and more recently has been shown to be strongly associated with depression risk [40]. Indeed, it is clear that understanding modifiable risk factors related to stress (and lifestyle) may be an important step in the prevention of inflammatory diseases like depression.

\section{Diet}

There have been substantial changes to dietary habits globally over recent decades, wherein dietary patterns high in fiber, nutrient-dense foods and omega-3 polyunsaturated fatty acids have been replaced by diets higher in saturated fats and refined sugars [41]. Whether diet quality contributes to psychopathology, particularly the common mental disorders (CMDs), depression and anxiety, has been a focus of much recent research. Since 2009, there have been numerous studies reporting inverse associations between diet quality and CMDs, both cross-sectionally [42-45] and prospectively [46-48]. These associations have also been shown in children [49] and adolescents [50-52] and are notably concordant across cultures. Individual nutrients are also related to depression. As an example, lowered availability of selenium in groundwater and lycopene contents in food are both associated with clinical depression [53-55].

One of the primary mechanisms of action proposed to explain these consistent relationships is that of inflammation, where diet quality can impact upon immune functioning and levels of systemic inflammation, which subsequently predisposes to depression. Data from population-based studies indicate an association between habitual diet quality and systemic inflammation. For example, in the Nurses' Health Study, a healthy ('prudent') dietary pattern, characterized by higher intakes of vegetables and fruit, whole grains, fish and legumes, was associated with reduced plasma concentrations of inflammatory markers, including CRP and IL-6; conversely, an unhealthy ('Western') pattern, high in red and processed meats, refined carbohydrate and other processed foods, was associated with increased inflammatory markers [56]. Similarly, Fung et al. [57] found that a Western dietary pattern was associated with higher levels of CRP in men participating in the Health Professionals Follow-up Study, while in the ATTICA study, a Mediterranean diet pattern was associated with lower inflammatory markers [58]. 
Various components of diet may also influence inflammation. For example, the fiber contained in whole grain foods appears to have immune modulating functions; wholegrain foods are rich in beta-glucans and these are known to promote immune functioning [59]. Fiber influences gut microbiota [60], and this has a knock-on effect on immune functioning [61]. In support of this, the consumption of whole grains is shown to be inversely associated with death from non-cardiovascular, non-cancer inflammatory diseases [62]. Whole grain foods are also high in phytochemicals, which protect against the oxidative stress that is a consequence of inflammation and a feature of depressive illness [63]. High glycemic load (GL) diets are a common feature of Western culture, being heavy in refined carbohydrates and added sugars. In middle-aged, otherwise healthy, women, a high GL diet was shown to be associated with higher levels of CRP [64], while another larger study reported that a high glycemic index diet was associated with a small but significant increase in CRP in more than 18,000 middle- to older-aged women [65]. Omega-3 fatty acids, which are important components of many healthy foods, such as seafood, nuts, legumes and leafy green vegetables, act to reduce inflammation [66], while a diet disproportionately high in omega- 6 fatty acids, which are commonly used in the production of processed foods, increases the production of pro-inflammatory cytokines [67]. In the Whitehall II cohort study, polyunsaturated fatty acid levels were inversely associated with CRP, while higher saturated fatty acid levels in serum phospholipids were associated with higher CRP and fibrinogen [68]. Transfatty acids similarly induce inflammation [69]. Finally, magnesium intake, which is highly correlated with diet quality [43], was shown to be inversely associated with CRP levels in the large National Health and Nutrition Survey (NHANES) in the US [70].

Intervention studies in humans support these observational data. Men randomized to a diet high in fruits and vegetables (eight servings per day) for eight weeks demonstrated a significant decrease in CRP compared with those consuming only two servings per day [71]. Similarly, Jenkins et al. [72] reported that a dietary intervention using a whole-diet approach and emphasizing the intake of soy, nuts and plant foods, resulted in pronounced reductions in CRP levels in hyperlipidemic patients over one month, independently of changes in body weight. Esposito et al. [73] also reported reductions in multiple inflammatory markers in patients with the metabolic syndrome randomized to a Mediterranean-style diet, long recognized as a healthful dietary pattern, independent of observed decreases in weight. Conversely, in an intervention study of overweight adults, a sucrose-rich diet for 10 weeks resulted in significant increases in the inflammatory markers haptoglobin and transferrin, and small increases in CRP [74].

Finally, studies in animal models explicate specific mechanisms of action. Recent studies show that rodents maintained on diets high in saturated fatty acids have elevated markers of brain inflammation [75]. This effect appears to be trans-generational; rats born to dams fed high saturated fat or high trans-fat diets were shown to have increased levels of neuroinflammation in adulthood, even when fed a standard diet post-weaning [76]. Saturated and trans-fat intake may influence inflammation, at least in part, via the health of the gut. High fat intake increases elements from gut microbiota, such as the endotoxin lipopolysaccharide (LPS), in the circulatory system, and LPS are potent promoters of immune system activation [77]. However, some of these deleterious effects on immune functioning may be addressed through the consumption of certain types of resistant starches and prebiotics [78]. In particular, short-chain fatty acids (SCFAs), which are produced by fermentation of dietary fiber by intestinal microbiota, appear to have a positive impact on immune functioning, suggesting that increasing intake of fermentable dietary fiber may be important in reducing inflammation [79]. There is an increasing focus on the importance of gut microbiota in depression and this is addressed in further detail below.

\section{Exercise}

There is a substantive evidence base on the role of exercise as an effective treatment strategy for depression $[80,81]$. It is also evident that habitual or regular exercise protects against the development of new depressive illnesses [82-84], and that physical inactivity during childhood is associated with an increased risk of depression in adulthood [85]. In a nested case-control study of older individuals, habitual physical activity reduced the likelihood of new depressive and anxiety disorders; for each standard deviation increase in physical activity score, there was a halving in the likelihood of developing depressive or anxiety disorders [82]. The relationship in this, and other studies [86-88], was found to be driven by leisure-time physical activity. Resistance training is a recognized treatment strategy for slowing loss of skeletal muscle mass and function [89]. A prospective cohort study in Tasmania reported that leisure-time physical activity is positively associated with leg strength and muscle quality in older women [90]. Sarcopenia is linked to elevated high sensitivity (hs) CRP [91], especially in the presence of obesity. Sarcopenia is further linked to cognitive decline in the elderly, which appears to be mediated by inflammation [92].

Acute exercise generates reactive oxygen species (ROS) [93] and inflammatory cytokines [94] that can transiently damage muscle cells, causing muscle fatigue, pain and 
inflammation. Contracting skeletal muscle produces a number of 'myokines', such as IL-6 [95], which impact systemically on lipid and glucose metabolism [96]. The pattern of inflammatory markers produced during acute exercise, characterized by a rapid elevation in levels of IL-6 that is quickly followed by induction of antiinflammatory substances, including IL-1ra, IL-10 and soluble tumor necrosis factor receptor (sTNF-R) [97], differs markedly from that in other inflammatory conditions, such as sepsis. Recovery after the exercise-induced IL-6 spike dampens the inflammatory response and oxidative burst activity [98]. Chronic or regular exercise, therefore, down-regulates systemic inflammation via homeostatic adaptation [99]. Similarly, fitness and exercise reduces leptin [100], elevated levels of which are also implicated in the development of depression [101] and is the most evidence-based management strategy for insulin resistance [102]. These data converge to provide evidence supporting a role for inflammation in exerciseinduced mood improvements.

More recently and conversely to the association between inflammation and exercise, the relationship between sedentary behavior and inflammation has become of increasing interest. Sedentary behavior is now considered an important and novel risk factor for a number of physical health conditions, independent of moderate to vigorous physical activity levels. Specifically, sedentary behavior has been shown to be associated with elevated adiposity and cardiovascular risk. For example, in a multi-ethnic study of atherosclerosis Allison et al. (2012) found sedentary behavior to be linked with "unfavorable" levels of adiposity-associated inflammation [103]. Further, in a national survey conducted in the US, Koster et al. [104] found sedentary behavior to be a predictor of mortality, after adjustment for relevant covariates. Complicating interpretation is that factors that are predictive of lower physical activity, such as lower self-efficacy, medical co-morbidity, lower educational status and social isolation, may be mediators or moderators of the association [105]. While the underlying physiology associated with inactivity is also not fully understood, there is evidence from animal studies that a sedentary lifestyle may suppress skeletal muscle lipoprotein lipase [106]; responsible for controlling the process associated with metabolic risk factors. Further research is required in order to fully understand the links between inflammation and the underlying physiology of sedentary behavior.

\section{Obesity}

Closely linked to diet are its consequences, including obesity, which is a growing public health concern linked to a host of chronic physical health conditions [107]. With the prevalence of obesity increasing to epidemic proportions, efforts in understanding associated risk factors and outcomes are continuing. The most recently collected data have shown that in excess of $60 \%$ of the Australian population exceed the recommended threshold for healthy body habitus [108]; concordant with estimates from other countries [109]. With few exceptions, both clinical- and community-based cross-sectional studies have consistently shown a relationship between obesity and depression regardless of methodological variability $[110,111]$. Prospective studies have suggested that obesity may be a clinical condition that predisposes to the development of depressive symptomatology as well as clinical depression [112]. Depression has also been shown to predispose to obesity in a bidirectional manner [112]. A recent meta-analysis of prospective cohort studies found obesity to increase the risk of later depression by $55 \%$, while depression increased the risk of developing obesity by $58 \%$ [113]. Further investigations into mechanistic pathways are much needed.

Obesity is an inflammatory state. Inflammatory cytokines have been found in abundance in fat cells, are involved in fat metabolism and have been observed to be positively associated with all indices of obesity, in particular abdominal obesity [114]. Altered adipocyte function, fatty acid levels, leptin and hypothalamic pituitary adrenal (HPA) axis dysfunction and oxidative stress are hypothesized to play a crucial but synergistic role in obesity-associated inflammation [114]. A reduction in adipose tissue mass, through calorie restriction in a group of obese women, was shown to reduce the ability of adipose tissue to produce TNFa, IL-6, IL- 8 and leptin [115]. Cross-sectional and prospective studies indicating obesity, independent of age and other potential confounders, leads to altered levels of inflammatory cytokines (or vice visa) provides a likely explanation into the observed increases in concomitant disease, including depression [116,117]. Moreover, we and others have previously shown inflammation, in particular, serum hsCRP to predict de novo major depressive disorder (MDD) [6].

\section{Smoking}

Rates of cigarette smoking are significantly higher in patients experiencing depression when compared with non-depressed controls. This finding has been replicated in numerous population-based epidemiological studies $[118,119]$. The causal relationship between smoking and depression is, however, a complex one. The three potential causal connections underpinning the cross-sectional relationship, that smoking leads to depression [120,121], that depression increases smoking behaviors [122], and that shared-vulnerability factors [123] increase the risk of both, are all supported by empirical evidence. Although it is probable that cigarette smoking exerts diverse psychological and neurobiological effects, which may increase one's predisposition to developing depression, one 
major pathway could be through enhancing systemic inflammatory and cell-mediated immune responses, and enhancing exposure to O\&NS.

Cigarette smoke contains many thousands of chemicals [124], including free radicals, metals, tars and other substances that induce inflammatory responses in bodily tissues and increase levels of O\&NS. The noxious effects of cigarette smoking in inducing altered inflammatory responses contribute to a number of chronic physical illnesses, including asthma, chronic obstructive pulmonary disease and atherosclerosis [125-127]. Smoking has been associated with increased levels of acute phase proteins, including CRP, and pro-inflammatory cytokines, including IL-1 $\beta$, IL- 6 and TNF- $\alpha$, which occur secondary to direct effects in activation of microglia and astrocytes [128]. These findings of increased proinflammatory cytokines are similar to those found in depressed patients [3]. Recent evidence also suggests that enhanced inflammatory responses are additive between cigarette smoking and depression, such that depressed smokers exhibit higher levels of hsCRP, IL- 6 and TNF $-\alpha$ than non-depressed smokers [129].

The exogenous free radicals contained in cigarette smoke lead to direct oxidative damage to cellular tissues, including those in the CNS. Numerous studies have demonstrated that animals exposed to cigarette smoke exhibit increased markers of oxidative stress and decreased levels of antioxidants. Observed effects include increased levels of thiobarbituric acid reactive substances (TBARS), superoxide, carbonylated proteins [130] and measures of lipid peroxidation [131-133], and reductions in levels of antioxidant enzymes, such as catalase [134], glutathione, superoxide dismutase [134], glutathione reductase, glutathione peroxidase and Vitamins A, C and E [135]. These findings appear most evident in models of chronic cigarette exposure, suggesting the possibility that early adaptive responses [136], which may increase antioxidant levels in the short term [137], are overwhelmed by chronic use. Once again, these findings are similar to those found in patients in major depression, where there appears to be a disturbance in the oxidant/antioxidant balance [3].

Significant interaction occurs between markers of inflammation and O\&NS, which further interact with numerous other key elements of central nervous system functioning, including neurotransmitter systems, neuroplastic neurotrophins, mitochondrial energy production and epigenetic controls. Through these diverse effects, in conjunction with its known ability to increase inflammatory and oxidative stress responses, cigarette smoking may increase susceptibility for the development of depression. The extent to which the susceptibility is increased will likely differ between individuals based on underlying depression risk, differing levels and timing of exposure to cigarette smoke (for example, childhood versus adulthood) and presence and severity of cigaretterelated health and social consequences.

\section{Gut permeability, the microbiome and the toll-like receptor (TLR)-IV pathway}

A new potential pathway that may mediate depression pathogenesis is increased immune responses against LPS of different commensal, gram negative bacteria. Clinical depression has recently been shown to be accompanied by increased plasma levels of immunoglobulin (Ig) A and/or IgM directed against a number of gram negative bacteria, including Hafnia alvei, Pseudomonas aeruginosa, Morganella morganii, Proteus mirabilis, Pseudomonas putida, Citrobacter koseri and Klebsielle pneumoniae [138-140]. All these gram negative bacteria belong to the normal gut flora [141,142]. These results suggest that there is an IgA- and IgM-mediated immune response directed against LPS, which is part of the bacterial wall of gram negative bacteria. LPS are toxic substances, which may activate immune cells by binding to the CD14-Toll-like receptor-4 (TLR4) complex. This in turn may activate intracellular signaling molecules, such as nuclear factor (NF)- $k \beta$, which in turn activates the production of pro-inflammatory cytokines, including TNF $\alpha$ and IL-1 and cyclo-oxygenase-2 (COX-2) $[143,144]$. The same processes also induce O\&NS pathways, for example, increased expression of inducible nitric oxide (iNOS) and thus NO [143]. LPS further activates nicotinamide adenine dinucleotide phosphate (NADPH) oxidase leading to an increased production of ROS, for example, peroxides, and superoxide $[145,146]$. Moreover, LPS increases the production of lysozyme (muramidase), which is produced by neutrophils, monocytes and glandular cells and which may bind LPS and therefore may decrease the activities of LPS [147].

The systemic IgM-mediated immune response in depression directed against LPS suggests that bacterial translocation may play a role in the inflammatory and O\&NS pathophysiology of clinical depression. Bacterial translocation indicates the presence of "leaky gut" or an increased permeability of the gut wall or loosening of the tight junction barrier. Under normal conditions, immune cells are geographically separated from gram negative bacteria in the gut. An increased permeability of the gut wall may allow poorly invasive gram negative bacteria to translocate into the mesenteric lymph nodes (MLNs) and sometimes into the systemic circulation $[148,149]$. Consequently, in the systemic circulation, IgM and IgA responses are mounted against the LPS of the bacterial wall, while IgA responses may be mounted even when the bacteria do not reach the blood stream, but only translocate into the MLNs. Thus, the assay of the IgA responses directed against LPS measures 
bacterial translocation into the blood stream and the MNLs. Once primed, immune cells may produce proinflammatory cytokines and stimulate O\&NS pathways [140]. Elevated plasma levels of IgA and IgM levels directed against the LPS of gram negative commensals indirectly indicate increased bacterial translocation and thus increased gut permeability. Therefore, bacterial translocation may drive inflammatory and O\&NS processes in depression, even in the absence of a specific inflammatory lesion [138]. On the other hand, inflammatory and O\&NS pathways may cause loosening of the tight junction barrier through NF- $\mathrm{kB}$ and pro-inflammatory cytokine-related mechanisms [150-154].

In a recent study, the IgM and/or IgA responses directed against LPS were found to be associated with signs of inflammation, O\&NS processes and even autoimmune responses [140]. More specifically, increased IgM and IgA responses to LPS in depression are significantly and positively correlated to plasma lysozyme, serum oxidized LDL antibodies and the IgM responses directed against azelaic acid and malondialdehyde and phosphatidylinsositol, and NO-adducts, such as NOtryptophan and NO-tyrosine [140]. These findings not only highlight O\&NS processes, but also oxidative damage to lipids and nitrosative damage to proteins, and autoimmune responses mounted against neoepitopes formed by O\&NS damage to lipids and proteins [140].

Thus, increased bacterial translocation may be a primary factor in the onset of clinical depression and may be a secondary factor further aggravating inflammatory and O\&NS pathways, leading to a vicious cycle between loosening of the tight junction barrier and activation of inflammatory and O\&NS pathways [138]. In addition, the IgM responses directed against LPS were significantly higher in patients with chronic depression than in those without chronic depression [155]. This may suggest that the inflammatory, O\&NS and autoimmune processes that are induced by bacterial translocation could be involved in the development of chronic depression and the neuroprogression that is observed in this condition $[3,4,139]$. Recently, translational data further underscored the importance of increased gut permeability in mediating stress-related behavioral responses, including depression [156]. Thus, stress activates the TLRIV pathway and associated inflammatory and O\&NS pathways, including central neuroinflammation. These effects are at least in part mediated by stress-induced intestinal permeability and bacterial translocation [156].

\section{Atopic disorders}

An elevated IgE response to common allergen exposure, leading to the development of allergic symptoms, such as asthma, eczema or allergic rhinitis/hay fever is defined as atopy [157]. The prevalence of atopic disorders has been steadily increasing over the past few decades $[158,159]$. Interestingly, atopy and depression have recently been linked. Although methodologies differ among studies, it has been consistently reported that atopic disorders are associated with an increased risk of both clinical depression and depressive symptomatology in clinical settings [160-163]. Population-based studies provide further support, showing a positive association between depression and atopic disorders [164-168]. As with all of the associations explored in this paper, the causal pathways and their mediators merit exploration.

Atopic disorders are the product of an inflammatory response. The interaction of an antigen, with antigenspecific IgE antibodies fixed on the mast cell surface, activates the mast cell to produce the release of inflammatory mediators [169]. There are three categories of mediators released; secretory granule-associated mediators (for example, histamine, proteoglycans, neutral proteases), lipid-derived mediators (for example, cycloxygenase and lipoxygenase metabolites of arachidonic acid) and cytokines (for example, Th2 response IL4, IL5 and IL13 and TNFa) [170]. This response results in an immediate hypersensitivity reaction, such as edema or itch of the skin, cough or bronchospasm, sneezing or increased mucous secretion. Many hypersensitivity reactions result in a second reaction, termed the late phase reaction (for example, persistent asthma) $[169,170]$.

\section{Dental cares and periodontal diseases}

Dental cares and periodontal diseases, including gingivitis and periodontitis, are diseases of the oral cavity where connective gum tissue gradually becomes detached from the alveolar bone and often leads to tooth loss [171]. Periodontal disease is a considerable public health concern; a recent prevalence estimate in US adults was $47 \%$ [172]. Correlates of periodontal disease include psychological factors, such as low self-esteem [173], loneliness [174] and high levels of stress [175]. It has been reported that psychiatric patients have poorer oral health status [176]. Recent research suggests that depression in particular may be associated with periodontal disease. For example, a large, epidemiological study of over 80,000 adults found that adults with depression were less likely to use oral health services, and adults with anxiety or depression were more likely to have tooth loss, even after controlling for various demographic and health factors, including use of oral health services [177]. However, another study comprising an older population found no association between depression and any measure of oral health, including periodontal disease [178]. Much of the limited research on psychological factors and periodontal disease examines samples from specialist or patient populations. Therefore, research 
which focuses on correlates of oral health and depression from community samples that are more representative of the general population, and that examines pathways and mediators of this association, are required.

Periodontal disease is an inflammatory disease. The accumulation of bacterial plaque on the teeth causes lesions in the periodontal tissue, leading to an acute, local inflammatory response [179]. Local inflammation in gingivitis is concentrated in soft oral tissues, such as the gum and connective tissue, while inflammation in supporting structures, including the alveolar bone, is also present in periodontitis [180]. Critically, periodontal disease is also associated with high levels of systemic inflammation, such as elevated serum levels of CRP [181]. Furthermore, it is a significant predictor of other inflammatory illnesses, such as CVD [182], and health outcomes, such as mortality in diabetes [183] and coronary artery disease [184]. The inflammatory response resulting from periodontal disease appears to be mediated by macrophages, which produce various cytokines [185], although periodontal tissues may also directly produce cytokines, such as IL-6 and IL-8 [186]. As such, periodontal disease may be a marker of a failure of the immune system to resolve inflammation $[187,188]$, a state that may also result in vulnerability to depression [189]. Furthermore, there may also be direct causal links between depression and periodontal disease, such as when periodontal disease increases risk for depression through the psychosocial effects of poor oral hygiene (for example, shame, isolation, loneliness) or more directly through the systemic inflammatory effects of periodontal disease that may potentiate inflammatory and O\&NS processes and thus depressive symptoms. Currently, there remains a dearth of evidence that examines whether translocation of periodontal bacteria plays a role in some patients with clinical depression, despite some evidence that periodontal infections may play a role in neurodegenerative disorders [190].

\section{Sleep}

Sleep is one of the most widely observed phenomena in multi-cellular organisms [191] and is recognized to play a vital regulatory role in a number of physiological and psychological systems. Abnormal sleep patterns are associated with a number of adverse health outcomes, such as an increased risk for mortality [192], morbidity and poorer quality of life [193]. Sleep disturbance is a common element in psychiatric disorders, and a complimentary marker of psychopathology in mood disorders [194]. It is estimated that up to 80 to $90 \%$ of individuals who suffer from a MDD also experience sleep disturbances [194-196]. Typically, depressive patients exhibit higher rates of sleep disturbances than those in the general population [197] and, conversely, those who report abnormal sleep patterns report higher levels of depression than normal sleepers [198]. Several prospective and epidemiological studies have suggested that sleep disturbances may also predispose individuals to subsequent development of mood disturbances. Indeed, a meta-analysis comprising relevant longitudinal epidemiological studies conducted by Riemann and Volderholzer [199] concluded that insomnia symptoms unambiguously represented a risk factor for the later development of depression. Similar research has suggested that insomnia symptoms often increase the risk of relapse in individuals previously diagnosed with MDD [200], and that periods of sleeplessness often precede manic episodes in bipolar patients [201].

Both chronic and acute sleep deprivation are associated with alteration in cellular and natural immune functioning [202]; however, the direct mechanism by which sleep affects inflammation is unclear. It is thought that alterations in sleep as a result of lifestyle or medical factors act as a moderator for inflammatory biomarkers [203] via a bidirectional relationship that exists to modulate host-defense and sleep mechanisms [192]. Experimental research has demonstrated that acute sleep deprivation results in impairments in immune functioning [202], characterized by increased levels of the proinflammatory cytokines, CRP, TFN- $\alpha$ [204] and IL-6 [205]. These alterations contribute to stroke and heart attack due to long-term impaired vascular endothelial function [206] and possible renal impairment [207]. Even modest sleep restriction (from eight to six hours per night) has been shown to result in elevation in levels of IL-6 and TFN- $\alpha$ [208]; however, this has not been replicated in epidemiological studies [209]. Increases in these biomarkers have also been observed naturally in individuals suffering primary insomnia [208,210]. Activation of these pro-inflammatory pathways may result from increased nocturnal sympathetic arousal [193] and an associated decline in natural immune functioning [202], therefore, facilitating potentially poorer cardiovascular outcomes and higher mortality risks previously seen in these individuals [192,211].

Growing research has suggested that curtailment of sleep is associated with similar neuroendocrine and neurobiological abnormalities observed in mood disturbances [212]. Increases in pro-inflammatory cytokines TFN- $\alpha$ and IL- 6 following sleep deprivation are also thought to be related to a reduction in adult neurogenesis (AN), comparable to those disturbances found in depressive patients [213]. Cytokines are significant modulators of mood (Krishnan and Nestler, [214]). The release of low doses of IL- 6 and TFN- $\alpha$ via administration of IL-1 in rats generates 'sickness behavior' (social withdrawal, decreased exploratory behavior) [2,215], while deletion of the gene encoding IL- 6 or TFN $\alpha$ promotes 
antidepressant-like behavior phenotypes (resistance to helplessness, enhanced hedonic behavior) [216]. Increased activation of the immune system is often observed in depressed patients; and those suffering immune diseases often report higher rates of depression [215]. It has, therefore, been proposed that inhibition of neurogenesis through the process of chronic sleep disruption may also contribute to the etiology of depression [217]. As both improved nocturnal sleep and successful pharmacological treatment of depression are associated with decreased levels of IL-6 [208,218], and similar inflammatory mechanisms appear to contribute to the pathogenesis of depression and expression of illness in chronic sleep disordered patients, adaptive sleep habits may, therefore, act as a protective factor against cardiovascular risk and poorer mental health outcomes.

\section{Vitamin D}

Low levels of Vitamin D, particularly 25-hydroxyvitamin D are widespread among Western populations [219], making it the most prevalent deficiency state. Low Vitamin $\mathrm{D}$ is linked to a diversity of adverse health outcomes, such as osteoporosis and cancer [220]. Notably, the physiology of vitamin D overlaps with the pathophysiology of depression. Vitamin $\mathrm{D}$ receptors are expressed in key brain areas; and vitamin D has a role in circadian rhythms and sleep, affects glucocorticoids and influences neuronal growth, cell proliferation in the developing brain and embryogenesis [221]. There is a growing epidemiological evidence-base linking depressive symptoms to low levels of serum 25-hydroxyvitamin D. These studies include both cross-sectional studies, as well as prospective data suggesting that low levels are associated with increased risk for the development of depression. There are positive trials of the potential antidepressant effects of vitamin D [222], although there are equally negative trials [223].

Vitamin D has well documented modulatory effects on immunity. It modulates immune responses to infections, such as tuberculosis [224]. In rats given a high fat diet, $1 \alpha$, 25-dihydroxyvitamin D3 (calcitriol) treatment reduced concentrations of various inflammatory markers, including TNF- $\alpha$, CRP and IL-6, and protected the liver from inflammatory damage [225]. In human studies, supplementation robustly reduces inflammatory markers in people with cystic fibrosis, including TNF- $\alpha$ and IL-6, but not other cytokines. Curiously, those two cytokines are the most robustly associated with depression in meta-analyses [226]. In multiple sclerosis, vitamin D reduces markers of inflammation and attenuates disease progression [227]. A one-year clinical trial of supplementation with Vitamin D in obese individuals reduced TNF- $\alpha$ levels, but increased hsCRP. The implications of these changes are unclear [225]. Inflammation and oxidative stress are tightly interlinked, and in human studies, vitamin D supplementation additionally reduced oxidative stress markers [228]. Vitamin D is a proxy of sunlight exposure, and it is useful to note that sunlight may suppress immunity via pathways other than via vitamin D. In fact, vitamin D derived from safe sunlight exposure may reduce systemic inflammation. There are additional skin photoreceptors that absorb ultraviolet light, and play a role in immunoregulation, that include DNA and lipids in skin cells and trans-urocanic acid found in the stratum corneum [229].

\section{Inflammation and immune activation across major psychiatric disorders}

There is also evidence that many other major psychiatric disorders are accompanied by activation of inflammatory and cell-mediated immune pathways, for example, mania, schizophrenia, post-traumatic stress disorder (PTSD). The first papers showing inflammation (increased levels of pronflammtory cytokines, such as IL-6 and acute phase proteins; [230,231] and immune activation (increased levels of sIL-2Rs levels [230,232] in acute and euthymic manic patients were published in the 1990s. A recent meta-analysis confirmed that mania and bipolar disorder are accompanied by activation of inflammatory, cellmediated and negative immunoregulatory cytokines [233]. Based on the first results obtained in schizophrenia, Smith and Maes in 1995 launched the monocyte-T lymphocyte theory of schizophrenia, which considered that activation of immuno-inflammatory processes may explain the neurodevelopmental pathology related to gestational infections. Results of recent meta-analyses showed that schizophrenia is accompanied by activation of inflammatory and cell mediated pathways [234]. PTSD patients also show higher levels of pro-inflammatory cytokines, including IL-1 [235], IL-6 [236,237] and TNF $\alpha$ [238].

It is evident that the sources of inflammation and immune activation, which play a role in depression, may contribute to the inflammatory burden in patients with mania. Schizophrenia is also associated with some but not all sources of inflammation and immune activation that play a role in depression. For example, a recent review showed that stress and trauma (first and second hits), nutritional factors and vitamin D may play a role in schizophrenia [239]. The strong associations among schizophrenia and smoking [240], obesity [241], some atopic disorders [242], sleep disorders [243] and poor periodontal and oral health [244,245] may further contribute to the inflammatory burden in schizophrenia patients. Other factors, however, may be more specific to mood disorders than to schizophrenia. For example, there is no significant association between schizophrenia and increased bacterial translocation [Maes et al., personal data]. There is strong comorbidity between depression 
and PTSD and patients with this comorbidity show increased inflammatory responses as compared with those with PTSD or depression alone [236,237]. The severity of stress and trauma [236], and the association between PTSD and smoking [246], obesity/metabolic syndrome [247], oral health status [248] and sleep disorders [249] may further aggravate the activation of immuno-inflammatory pathways in PTSD or comorbid PTSD and depression.

\section{Summary}

In interpreting these data, a number of factors need to be borne in mind. First, depression is a very pleomorphic and heterogeneous phenotype, and there are likely to be substantial differences in results depending whether studies examine clinical or non-clinical samples, use cut scores on rating scales or formal structured interviews and so on. Similarly, many studies do not control for potential confounders, and most of the literature is cross-sectional. Last, the areas of interest diverge greatly in terms of the quantity and quality of the extant literature, with a clear picture emerging on some areas, such as trauma and stress, and others remaining areas for future investigation.

The identification of a number of potential factors that are known sources of inflammation, and their correlation to quality evidence linking those factors to increased risk of depression, provides mechanistic support for inflammation as one of the mediating pathways to both risk and neuroprogression in depression. The pivotal element is that most of these are plastic, and amenable to intervention, both therapeutic and preventative. While inflammation has suggested a number of very promising anti-inflammatory therapies, including statins, aspirin, pioglitazone and celecoxib, the latter preventative need is perhaps the more pressing [14,250,251]. Psychiatry largely lacks an integrated model for conceptualizing modifiable risk factors for depression. It has, therefore, lacked conceptually and pragmatically coherent primary prevention strategies, prioritizing the treatment of established disorders. Yet the rationale, targets and imperative to focus on prevention of depression at a population level is clear.

\footnotetext{
Abbreviations

CIRS: Compensatory anti-inflammatory reflex system; CMDs: Common mental disorders; CNS: Central nervous system; COX-2: Cyclo-oxygenase-2; CRP: C-reactive protein; CVD: Cardiovascular disease; HPA axis: Hypothalamic pituitary adrenal axis; hs: High sensitivity; IFN: Interferon; Ig: Immunoglobulin; IL: Interleukin; iNOS: Inducible nitric oxide; LPS: Lipopolysaccharide; MDD: Major depressive disorder; MLNs: Mesenteric lymph nodes; NADPH: Nicotinamide adenine dinucleotide phosphate; NHANES: National Health and Nutrition Survey; NF: Nuclear factor; O\&NS: Oxidative and nitrosative stress; PTSD: Post-traumatic stress disorder; ROS: Reactive oxygen species; SCFAs: Short-chain fatty acids; SSRIs: Selective serotonin reuptake inhibitors; sTNF-R: Soluble tumor necrosis factor receptor; TNF: Tumor necrosis factor; TBARS: Thiobarbituric acid reactive substances; TLR: Toll-like receptor.
}

\section{Competing interests}

MB has received Grant/Research Support from the NIH, Cooperative Research Centre, Simons Autism Foundation, Cancer Council of Victoria, Stanley Medical Research Foundation, MBF, NHMRC, Beyond Blue, Rotary Health, Geelong Medical Research Foundation, Bristol Myers Squibb, Eli Lilly, Glaxo SmithKline, Organon, Novartis, Mayne Pharma and Servier; has been a speaker for Astra Zeneca, Bristol Myers Squibb, Eli Lilly, Glaxo SmithKline, Janssen Cilag, Lundbeck, Merck, Pfizer, Sanofi Synthelabo, Servier, Solvay and Wyeth; and served as a consultant to Astra Zeneca, Bristol Myers Squibb, Eli Lilly, Glaxo SmithKline, Janssen Cilag, Lundbeck Merck and Servier. FJ has received Grant/Research support from the Brain and Behaviour Research Institute, the National Health and Medical Research Council (NHMRC), Australian Rotary Health, the Geelong Medical Research Foundation, the lan Potter Foundation, Eli Lilly and The University of Melbourne, and has been a paid speaker for Sanofi-Synthelabo, Janssen Cilag, Servier, Pfizer, Health Ed, Network Nutrition and Eli Lilly. She is currently supported by an NHMRC Training Fellowship (\#628912).

LW, JP, SM, AH and MM have no conflicts of interest, including specific financial interests and relationships and affiliations relevant to the subject matter or materials discussed in the manuscript.

\section{Authors' contributions}

$M B$ took part in the conception and design of the study, critically revised the manuscript and took primary responsibility for writing the manuscript. LW, FJ, AO, JP, SM, NA, AS, AH, MLB and MM took part in writing the manuscript and critically revised the manuscript. All authors read and approved the final manuscript.

\section{Author details}

${ }^{1}$ IMPACT Strategic Research Centre, School of Medicine, Deakin University, Geelong, VIC, Australia. 'Department of Psychiatry, University of Melbourne, Parkville, VIC, Australia. ${ }^{3}$ Florey Institute of Neuroscience and Mental Health, Parkville, VIC, Australia. ${ }^{4}$ Orygen Youth Health Research Centre, Parkville, VIC, Australia. ${ }^{5}$ School of Public health and Preventive Medicine, Monash University, Melbourne, VIC, Australia. ${ }^{6}$ NorthWest Academic Centre, Department of Medicine, The University of Melbourne, St Albans, VIC, Australia. ${ }^{7}$ Melbourne School of Psychological Sciences, University of Melbourne, Parkville, VIC, Australia. ${ }^{8}$ Department of Psychiatry, Chulalongkorn University, Rama Road, Bangkok, Thailand.

Received: 8 February 2013 Accepted: 31 May 2013 Published: 12 September 2013

\section{References}

1. Maes M: Evidence for an immune response in major depression: a review and hypothesis. Prog Neuropsychopharmacol Biol Psychiatry 1995, 19:11-38.

2. Maes M, Berk M, Goehler L, Song C, Anderson G, Galecki P, Leonard B: Depression and sickness behavior are Janus-faced responses to shared inflammatory pathways. BMC Med 2012, 10:66.

3. Moylan S, Maes M, Wray NR, Berk M: The neuroprogressive nature of major depressive disorder: pathways to disease evolution and resistance, and therapeutic implications. Mol Psychiatry 2012, 18:595-606.

4. Leonard B, Maes M: Mechanistic explanations how cell-mediated immune activation, inflammation and oxidative and nitrosative stress pathways and their sequels and concomitants play a role in the pathophysiology of unipolar depression. Neurosci Biobehav Rev 2012, 36:764-785.

5. Dowlati Y, Herrmann N, Swardfager W, Liu H, Sham L, Reim EK, Lanctot KL: A meta-analysis of cytokines in major depression. Biol Psychiatry 2010, 67:446-457

6. Pasco JA, Nicholson GC, Williams LJ, Jacka FN, Henry MJ, Kotowicz MA, Schneider HG, Leonard BE, Berk M: Association of high-sensitivity C-reactive protein with de novo major depression. Br J Psychiatry 2010, 197:372-377.

7. Reichenberg A, Yirmiya R, Schuld A, Kraus T, Haack M, Morag A, Pollmacher T: Cytokine-associated emotional and cognitive disturbances in humans. Arch Gen Psychiatry 2001, 58:445-452.

8. Udina M, Castellvi P, Moreno-Espana J, Navines R, Valdes M, Forns X, Langohr K, Sola R, Vieta E, Martin-Santos R: Interferon-induced depression in chronic hepatitis C: a systematic review and meta-analysis. $J$ Clin Psychiatry 2012, 73:1128-1138. 
9. Connor TJ, Leonard BE: Depression, stress and immunological activation: the role of cytokines in depressive disorders. Life Sci 1998, 62:583-606.

10. Xia Z, DePierre JW, Nassberger L: Tricyclic antidepressants inhibit IL-6, IL-1 beta and TNF-alpha release in human blood monocytes and IL-2 and interferon-gamma in T cells. Immunopharmacology 1996, 34:27-37.

11. Maes M, Song C, Lin AH, Bonaccorso S, Kenis G, De Jongh R, Bosmans E, Scharpe S: Negative immunoregulatory effects of antidepressants: inhibition of interferon-gamma and stimulation of interleukin-10 secretion. Neuropsychopharmacology 1999, 20:370-379.

12. Galecki P, Galecka E, Maes M, Chamielec M, Orzechowska A, Bobinska K, Lewinski A, Szemraj J: The expression of genes encoding for COX-2, MPO, iNOS, and SPLA2-IIA in patients with recurrent depressive disorder. $J$ Affect Disord 2012, 138:360-366.

13. Cattaneo A, Gennarelli M, Uher R, Breen G, Farmer A, Aitchison KJ, Craig IW, Anacker C, Zunsztain PA, McGuffin P, Pariante CM: Candidate genes expression profile associated with antidepressants response in the GENDEP study: differentiating between baseline 'predictors' and longitudinal 'targets'. Neuropsychopharmacology 2013, 38:377-385.

14. Maes M, Fisar Z, Medina M, Scapagnini G, Nowak G, Berk M: New drug targets in depression: inflammatory, cell-mediated immune, oxidative and nitrosative stress, mitochondrial, antioxidant, and neuroprogressive pathways. And new drug candidates--Nrf2 activators and GSK-3 inhibitors. Inflammopharmacology 2012, 20:127-150.

15. Hannestad J, DellaGioia N, Bloch M: The effect of antidepressant medication treatment on serum levels of inflammatory cytokines: a meta-analysis. Neuropsychopharmacology 2011, 36:2452-2459.

16. Eller T, Vasar V, Shlik J, Maron E: Pro-inflammatory cytokines and treatment response to escitalopram in major depressive disorder. Prog Neuropsychopharmacol Biol Psychiatry 2008, 32:445-450.

17. Maes M, Ombelet W, De Jongh R, Kenis G, Bosmans E: The inflammatory response following delivery is amplified in women who previously suffered from major depression, suggesting that major depression is accompanied by a sensitization of the inflammatory response system. J Affect Disord 2001, 63:85-92.

18. Moller M, Du Preez JL, Viljoen F, Berk M, Emsley R, Harvey BH: Social isolation rearing induces immunological, neurochemical, mitochondrial and behavioural deficits in rats, and is reversed by clozapine or $\mathrm{N}$-acetyl cysteine. Brain Behav Immun 2012, 18:156-167.

19. Persoons JH, Schornagel K, Breve J, Berkenbosch F, Kraal G: Acute stress affects cytokines and nitric oxide production by alveolar macrophages differently. Am J Respir Crit Care Med 1995, 152:619-624.

20. Nguyen KT, Deak T, Owens SM, Kohno T, Fleshner M, Watkins LR, Maier SF: Exposure to acute stress induces brain interleukin-1beta protein in the rat. J Neurosci 1998, 18:2239-2246.

21. Maier SF, Watkins LR: Intracerebroventricular interleukin-1 receptor antagonist blocks the enhancement of fear conditioning and interference with escape produced by inescapable shock. Brain Res 1995, 695:279-282.

22. Kubera M, Symbirtsev A, Basta-Kaim A, Borycz J, Roman A, Papp M, Claesson M: Effect of chronic treatment with imipramine on interleukin 1 and interleukin 2 production by splenocytes obtained from rats subjected to a chronic mild stress model of depression. Pol J Pharmacol 1996, 48:503-506.

23. Zhou D, Kusnecov AW, Shurin MR, DePaoli M, Rabin BS: Exposure to physical and psychological stressors elevates plasma interleukin 6: relationship to the activation of hypothalamic-pituitary-adrenal axis. Endocrinology 1993, 133:2523-2530.

24. Kubera M, Obuchowicz E, Goehler L, Brzeszcz J, Maes M: In animal models, psychosocial stress-induced (neuro)inflammation, apoptosis and reduced neurogenesis are associated to the onset of depression. Prog Neuropsychopharmacol Biol Psychiatry 2011, 35:744-759.

25. Dobbin JP, Harth M, McCain GA, Martin RA, Cousin K: Cytokine production and lymphocyte transformation during stress. Brain Behav Immun 1991, 5:339-348.

26. Mittwoch-Jaffe T, Shalit F, Srendi B, Yehuda S: Modification of cytokine secretion following mild emotional stimuli. Neuroreport 1995, 6:789-792.

27. Deinzer R, Forster P, Fuck L, Herforth A, Stiller-Winkler R, Idel H: Increase of crevicular interleukin 1 beta under academic stress at experimental gingivitis sites and at sites of perfect oral hygiene. J Clin Periodontol 1999, 26:1-8.
28. Maes M, Song C, Lin A, De Jongh R, Van Gastel A, Kenis G, Bosmans E, De Meester I, Benoy I, Neels H, Demedts P, Janca A, Scharpé S, Smith RS: The effects of psychological stress on humans: increased production of pro-inflammatory cytokines and a Th1-like response in stress-induced anxiety. Cytokine 1998, 10:313-318.

29. Maes M, Song C, Lin A, DeJong R, van Gastel A, Kenis G, Bosmans E, DeMeester I, Neels H, Janca A, Scharpe S, Smith RS: Immune and Clinical Correlates of Psychological Stress-Induced Production of Interferon- $\gamma$ and IL-10 in Humans. In Edited by Plotnikoff NP, Faith RE, Murgo AJ, Good RA. Boca Raton, FL: Raven Press; 1998. chapter 3.

30. Song C, Kenis G, van Gastel A, Bosmans E, Lin A, de Jong R, Neels H, Scharpe S, Janca A, Yasukawa K, Maes M: Influence of psychological stress on immune-inflammatory variables in normal humans. Part II. Altered serum concentrations of natural anti-inflammatory agents and soluble membrane antigens of monocytes and T lymphocytes. Psychiatry Res 1999, 85:293-303.

31. Maes M, Kubera M, Obuchowiczwa E, Goehler L, Brzeszcz J: Depression's multiple comorbidities explained by (neuro)inflammatory and oxidative \& nitrosative stress pathways. Neuro Endocrinol Lett 2011, 32:7-24.

32. Danese A, Pariante CM, Caspi A, Taylor A, Poulton R: Childhood maltreatment predicts adult inflammation in a life-course study. Proc Natl Acad Sci USA 2007, 104:1319-1324

33. Kiecolt-Glaser J, Gouin J, Weng N, Malarkey W, Beversdorf D, Glasert R: Childhood adversity heightens the impact of later-life caregiving stress on telomere length and inflammation. Psychosom Med 2011, 73:16-22.

34. Miller GE, Cole SW: Clustering of depression and inflammation in adolescents previously exposed to childhood adversity. Biol Psychiatry 2012, 72:34-40.

35. Korkeila J, Vahtera J, Korkeila K, Kivimäki M, Sumanen M, Koskenvuo K, Koskenvuo M: Childhood adversities as predictors of incident coronary heart disease and cerebrovascular disease. Heart 2010, 96:298-303.

36. Mclntyre RS, Soczynska JK, Liauw SS, Woldeyohannes HO, Brietzke E, Nathanson J, Alsuwaidan M, Muzina DJ, Taylor VH, Cha DS, Kennedy SH: The association between childhood adversity and components of metabolic syndrome in adults with mood disorders: results from the international mood disorders collaborative project. Int I Psychiatry Med 2012, 43:165-177.

37. Wadee AA, Kuschke RH, Kometz S, Berk M: Personality factors, stress and immunity. Stress Heal 2001, 17:25-40.

38. Slavich GM, O'Donovan A, Epel ES, Kemeny ME: Black sheep get the blues: a psychobiological model of social rejection and depression. Neurosci Biobehav Rev 2010, 35:39-45.

39. Emeny R, Lacruz M-E, Baumert J, Zierer A, von Eisenhart Rothe A, Autenrieth C, Herder C, Koenig W, Thorand B, Ladwig K-H: Job strain associated CRP is mediated by leisure time physical activity: results from the MONICA/ KORA study. Brain Behav Immun 2012, 26:1077-1084.

40. LaMontagne AD, Keegel T, Vallance D, Ostry A, Wolfe R: Job strain attributable depression in a sample of working Australians: assessing the contribution to health inequalities. BMC Publ Health 2008, 8:181.

41. Drewnowski A, Popkin BM: The nutrition transition: new trends in the global diet. Nutr Rev 1997, 55:31-43.

42. Jacka FN, Pasco JA, Mykletun A, Williams LJ, Hodge AM, O'Reilly SL, Nicholson GC, Kotowicz MA, Berk M: Association of Western and traditional diets with depression and anxiety in women. Am J Psychiatry 2010, 167:305-311.

43. Jacka FN, Mykletun A, Berk M, Bjelland I, Tell GS: The association between habitual diet quality and the common mental disorders in communitydwelling adults: the Hordaland Health Study. Psychosom Med 2011, 73:483-490.

44. Nanri A, Kimura Y, Matsushita Y, Ohta M, Sato M, Mishima N, Sasaki S, Mizoue T: Dietary patterns and depressive symptoms among Japanese men and women. Eur J Clin Nutr 2010, 64:832-839.

45. Kuczmarski MF, Cremer Sees A, Hotchkiss L, Cotugna N, Evans MK, Zonderman AB: Higher healthy eating index-2005 scores associated with reduced symptoms of depression in an urban population: findings from the Healthy Aging in Neighborhoods of Diversity Across the Life Span (HANDLS) study. J Am Diet Assoc 2010, 110:383-389.

46. Akbaraly TN, Brunner EJ, Ferrie JE, Marmot MG, Kivimaki M, Singh-Manoux A: Dietary pattern and depressive symptoms in middle age. Br J Psychiatry 2009, 195:408-413. 
47. Sanchez-Villegas A, Delgado-Rodriguez M, Alonso A, Schlatter J, Lahortiga F, Serra Majem L, Martinez-Gonzalez MA: Association of the Mediterranean dietary pattern with the incidence of depression: the Seguimiento Universidad de Navarra/University of Navarra follow-up (SUN) cohort. Arch Gen Psychiatry 2009, 66:1090-1098.

48. Sanchez-Villegas A, Toledo E, de Irala J, Ruiz-Canela M, Pla-Vidal J, MartinezGonzalez MA: Fast-food and commercial baked goods consumption and the risk of depression. Public Health Nutr 2012, 15:424-432.

49. Kohlboeck G, Sausenthaler S, Standl M, Koletzko S, Bauer CP, von Berg A, Berdel D, Kramer U, Schaaf B, Lehmann I, Herbarth O, Herbarth JH, GINI-plus and LISA-plus Study: Food intake, diet quality and behavioral problems in children: results from the GINI-plus/LISA-plus studies. Ann Nutr Metab 2012, 60:247-256.

50. Jacka FN, Kremer PJ, Berk M, de Silva-Sanigorski AM, Moodie M, Leslie ER Pasco JA, Swinburn BA: A prospective study of diet quality and mental health in adolescents. PLOS One 2011, 6:e24805

51. Jacka FN, Kremer PJ, Leslie ER, Berk M, Patton GC, Toumbourou JW, Williams JW: Associations between diet quality and depressed mood in adolescents: results from the Australian Healthy Neighbourhoods Study. Aust N Z J Psychiatry 2010, 44:435-442.

52. Weng TT, Hao JH, Qian QW, Cao H, Fu JL, Sun Y, Huang L, Tao FB: Is there any relationship between dietary patterns and depression and anxiety in Chinese adolescents? Public Health Nutr 2012, 15:673-682.

53. Niu K, Guo H, Kakizaki M, Cui Y, Ohmori-Matsuda K, Guan L, Hozawa A, Kuriyama S, Tsuboya T, Ohrui T, Furukawa K, Arai H, Tsuji I, Nagatomi R: A tomato-rich diet is related to depressive symptoms among an elderly population aged 70 years and over: a population-based, cross-sectional analysis. J Affect Disord 2013, 144:165-170.

54. Johnson LA, Phillips JA, Mauer C, Edwards M, Balldin VH, Hall JR, Barber R, Conger TL, O'Bryant SE: The impact of GPX1 on the association of groundwater selenium and depression: a project FRONTIER study. BMC Psychiatry 2013, 13:7

55. Maes M, Christophe A, Delanghe J, Altamura C, Neels H, Meltzer HY: Lowered omega3 polyunsaturated fatty acids in serum phospholipids and cholesteryl esters of depressed patients. Psychiatry Res 1999, 85:275-291.

56. Lopez-Garcia E, Schulze MB, Fung TT, Meigs JB, Rifai N, Manson JE, Hu FB: Major dietary patterns are related to plasma concentrations of markers of inflammation and endothelial dysfunction. Am J Clin Nutr 2004, 80:1029-1035

57. Fung TT, Rimm EB, Spiegelman D, Rifai N, Tofler GH, Willett WC, Hu FB: Association between dietary patterns and plasma biomarkers of obesity and cardiovascular disease risk. Am J Clin Nutr 2001, 73:61-67.

58. Chrysohoou C, Panagiotakos DB, Pitsavos C, Das UN, Stefanadis C: Adherence to the Mediterranean diet attenuates inflammation and coagulation process in healthy adults: The ATTICA Study. J Am Coll Cardiol 2004, 44:152-158.

59. Volman JJ, Ramakers JD, Plat J: Dietary modulation of immune function by beta-glucans. Physiol Behav 2008, 94:276-284.

60. Tachon S, Zhou J, Keenan M, Martin R, Marco ML: The intestinal microbiota in aged mice is modulated by dietary resistant starch and correlated with improvements in host responses. FEMS Microbiol Ecol 2013, 83:299-309.

61. Parikh S, Pollock NK, Bhagatwala J, Guo DH, Gutin B, Zhu H, Dong Y: Adolescent fiber consumption is associated with visceral fat and inflammatory markers. J Clin Endocrinol Metab 2012, 97:E1451-1457.

62. Jacobs DR Jr, Andersen LF, Blomhoff R: Whole-grain consumption is associated with a reduced risk of noncardiovascular, noncancer death attributed to inflammatory diseases in the lowa Women's Health Study. Am J Clin Nutr 2007, 85:1606-1614.

63. Bilici M, Efe H, Koroglu MA, Uydu HA, Bekaroglu M, Deger O: Antioxidative enzyme activities and lipid peroxidation in major depression: alterations by antidepressant treatments. J Affect Disord 2001, 64:43-51.

64. Liu S, Manson JE, Buring JE, Stampfer MJ, Willett WC, Ridker PM: Relation between a diet with a high glycemic load and plasma concentrations of high-sensitivity C-reactive protein in middle-aged women. Am J Clin Nutr 2002, 75:492-498.

65. Levitan EB, Cook NR, Stampfer MJ, Ridker PM, Rexrode KM, Buring JE, Manson JE, Liu S: Dietary glycemic index, dietary glycemic load, blood lipids, and C-reactive protein. Metabolism 2008, 57:437-443.

66. Rangel-Huerta OD, Aguilera CM, Mesa MD, Gil A: Omega-3 long-chain polyunsaturated fatty acids supplementation on inflammatory biomakers: a systematic review of randomised clinical trials. $\mathrm{Br} J$ Nutr 2012, 107:S159-170.

67. Simopoulos AP: The importance of the ratio of omega-6/omega-3 essential fatty acids. Biomed Pharmacother 2002, 56:365-379.

68. Clarke R, Shipley M, Armitage J, Collins R, Harris W: Plasma phospholipid fatty acids and CHD in older men: Whitehall study of London civil servants. Br J Nutr 2009, 102:279-284

69. Iwata NG, Pham M, Rizzo NO, Cheng AM, Maloney E, Kim F: Trans fatty acids induce vascular inflammation and reduce vascular nitric oxide production in endothelial cells. PLoS One 2011, 6:e29600.

70. King DE, Mainous AG 3rd, Geesey ME, Woolson RF: Dietary magnesium and C-reactive protein levels. J Am Coll Nutr 2005, 24:166-171.

71. Watzl B, Kulling SE, Moseneder J, Barth SW, Bub A: A 4-wk intervention with high intake of carotenoid-rich vegetables and fruit reduces plasma C-reactive protein in healthy, nonsmoking men. Am J Clin Nutr 2005, 82:1052-1058.

72. Jenkins DJ, Kendall CW, Marchie A, Faulkner DA, Wong JM, de Souza R, Emam A, Parker TL, Vidgen E, Lapsley KG, Trautwein EA, Josse RG, Leiter LA Connelly PW: Effects of a dietary portfolio of cholesterol-lowering foods vs lovastatin on serum lipids and C-reactive protein. JAMA 2003, 290:502-510.

73. Esposito K, Marfella R, Ciotola M, Di Palo C, Giugliano F, Giugliano G, D'Armiento M, D'Andrea F, Giugliano D: Effect of a Mediterranean-style diet on endothelial dysfunction and markers of vascular inflammation in the metabolic syndrome: a randomized trial. JAMA 2004, 292:1440-1446.

74. Sorensen LB, Raben A, Stender S, Astrup A: Effect of sucrose on inflammatory markers in overweight humans. Am J Clin Nutr 2005, 82:421-427.

75. Pistell PJ, Morrison CD, Gupta S, Knight AG, Keller JN, Ingram DK, BruceKeller AJ: Cognitive impairment following high fat diet consumption is associated with brain inflammation. J Neuroimmunol 2012, 219:25-32.

76. Bilbo SD, Tsang V: Enduring consequences of maternal obesity for brain inflammation and behavior of offspring. FASEB J 2012, 24:2104-2115.

77. Moreira AP, Texeira TF, Ferreira AB, Peluzio Mdo C, Alfenas Rde C: Influence of a high-fat diet on gut microbiota, intestinal permeability and metabolic endotoxaemia. Br J Nutr 2012, 108:801-809.

78. Delzenne NM, Neyrinck AM, Cani PD: Modulation of the gut microbiota by nutrients with prebiotic properties: consequences for host health in the context of obesity and metabolic syndrome. Microb Cell Fact 2012, 10:S10.

79. Maslowski KM, Vieira AT, Ng A, Kranich J, Sierro F, Yu D, Schilter HC, Rolph MS, Mackay F, Artis D, Xavier RJ, Teixeira MM, Mackay CR: Regulation of inflammatory responses by gut microbiota and chemoattractant receptor GPR43. Nature 2009, 461:1282-1286.

80. Conn VS: Depressive symptom outcomes of physical activity interventions: meta-analysis findings. Ann Behav Med 2010, 39:128-138.

81. Greist JH, Klein MH, Eischens RR, Faris J, Gurman AS, Morgan WP: Running as treatment for depression. Compr Psychiatry 1979, 20:41-54.

82. Pasco JA, Williams LJ, Jacka FN, Henry MJ, Coulson CE, Brennan SL, Leslie E, Nicholson GC, Kotowicz MA, Berk M: Habitual physical activity and the risk for depressive and anxiety disorders among older men and women. Int Psychogeriatr 2011, 23:292-298.

83. Strawbridge WJ, Deleger S, Roberts RE, Kaplan GA: Physical activity reduces the risk of subsequent depression for older adults. Am J Epidemiol 2002, 156:328-334.

84. Brown WJ, Ford JH, Burton NW, Marshall AL, Dobson AJ: Prospective study of physical activity and depressive symptoms in middle-aged women. Am J Prev Med 2005, 29:265-272.

85. Jacka FN, Pasco JA, Williams LJ, Leslie ER, Dodd S, Nicholson GC, Kotowicz MA, Berk M: Lower levels of physical activity in childhood associated with adult depression. J Sci Med Sport 2010, 14:222-226.

86. Farmer ME, Locke BZ, Moscicki EK, Dannenberg AL, Larson DB, Radloff LS: Physical activity and depressive symptoms: the NHANES I Epidemiologic Follow-up Study. Am J Epidemiol 1988, 128:1340-1351.

87. Wiles NJ, Haase AM, Gallacher J, Lawlor DA, Lewis G: Physical activity and common mental disorder: results from the Caerphilly study. Am $J$ Epidemiol 2007, 165:946-954.

88. Sanchez-Villegas A, Ara I, Guillen-Grima F, Bes-Rastrollo M, VaroCenarruzabeitia JJ, Martinez-Gonzalez MA: Physical activity, sedentary index, and mental disorders in the SUN cohort study. Med Sci Sports Exerc 2008, 40:827-834. 
89. Chodzko-Zajko WJ, Proctor DN, Fiatarone Singh MA, Minson CT, Nigg CR, Salem GJ, Skinner JS: American College of Sports Medicine position stand. Exercise and physical activity for older adults. Med Sci Sports Exerc 2009, 41:1510-1530.

90. Scott D, Blizzard L, Fell J, Jones G: Ambulatory activity, body composition, and lower-limb muscle strength in older adults. Med Sci Sports Exerc 2009, 41:383-389.

91. Kim T, Park M, Lim K, Choi H, Yang S, Yoo H, Kang H, Song W, Choi H, Baik S, Choi DS, Choi KM: Relationships between sarcopenic obesity and insulin resistance, inflammation, and Vitamin D status: the Korean Sarcopenic Obesity Study (KSOS). Clin Endocrinol (Oxf) 2012.

92. Canon ME, Crimmins EM: Sex differences in the association between muscle quality, inflammatory markers, and cognitive decline. J Nutr Health Aging 2011, 15:695-698.

93. Sachdev S, Davies KJ: Production, detection, and adaptive responses to free radicals in exercise. Free Radic Biol Med 2008, 44:215-223.

94. Kramer HF, Goodyear LJ: Exercise, MAPK, and NF-kappaB signaling in skeletal muscle. J Appl Physiol 2007, 103:388-395.

95. Febbraio MA, Pedersen BK: Muscle-derived interleukin-6: mechanisms for activation and possible biological roles. FASEB J 2002, 16:1335-1347.

96. Pedersen BK, Fischer CP: Physiological roles of muscle-derived interleukin6 in response to exercise. Curr Opin Clin Nutr Metab Care 2007, 10:265-271.

97. Ostrowski K, Rohde T, Asp S, Schjerling P, Pedersen BK: Pro- and antiinflammatory cytokine balance in strenuous exercise in humans. J Physiol 1999, 515:287-291.

98. Walsh NP, Gleeson M, Shephard RJ, Gleeson M, Woods JA, Bishop NC, Fleshner M, Green C, Pedersen BK, Hoffman-Goetz L, Rogers CJ, Northoff H, Abbasi A, Simon P: Position statement. Part one: Immune function and exercise. Exerc Immunol Rev 2011, 17:6-63.

99. Teixeira de Lemos E, Pinto R, Oliveira J, Garrido P, Sereno J, MascarenhasMelo F, Pascoa-Pinheiro J, Teixeira F, Reis F: Differential effects of acute (extenuating) and chronic (training) exercise on inflammation and oxidative stress status in an animal model of type 2 diabetes mellitus. Mediators Inflamm 2011, 2011:253061

100. Bobbert T, Mai K, Brechtel L, Schulte HM, Weger B, Pfeiffer AF, Spranger J, Diederich S: Leptin and endocrine parameters in marathon runners. Int J Sports Med 2012, 33:244-248.

101. Pasco JA, Jacka FN, Williams LJ, Henry MJ, Nicholson GC, Kotowicz MA, Berk M: Leptin in depressed women: cross-sectional and longitudinal data from an epidemiologic study. J Affect Disord 2008, 107:221-225.

102. Stuart MJ, Baune BT: Depression and type 2 diabetes: inflammatory mechanisms of a psychoneuroendocrine co-morbidity. Neurosci Biobehav Rev 2012, 36:658-676.

103. Allison MA, Jensky NE, Marshall SJ, Bertoni AG, Cushman M: Sedentary behavior and adiposity-associated inflammation: the Multi-Ethnic Study of Atherosclerosis. Am J Prev Med 2012, 42:8-13.

104. Koster A, Caserotti P, Patel KV, Matthews CE, Berrigan D, Van Domelen DR, Brychta RJ, Chen KY, Harris TB: Association of sedentary time with mortality independent of moderate to vigorous physical activity. PLOS One 2012, 7:e37696.

105. Vancampfort $D$, Correll CU, Probst M, Sienaert P, Wyckaert S, De Herdt A Knapen J, De Wachter D, De Hert M: A review of physical activity correlates in patients with bipolar disorder. J Affect Disord 2013, 105:285-291.

106. Hamilton MT, Hamilton DG, Zderic TW: Role of low energy expenditure and sitting in obesity, metabolic syndrome, type 2 diabetes, and cardiovascular disease. Diabetes 2007, 56:2655-2667.

107. Racette SB, Deusinger SS, Deusinger RH: Obesity: overview of prevalence, etiology, and treatment. Phys Ther 2003, 83:276-288.

108. Pasco JA, Nicholson GC, Brennan SL, Kotowicz MA: Prevalence of obesity and the relationship between the body mass index and body fat: crosssectional, population-based data. PLoS One 2012, 7:e29580.

109. Kopelman PG: Obesity as a medical problem. Nature 2000, 404:635-643.

110. de Wit L, Luppino F, van Straten A, Penninx B, Zitman F, Cuijpers P: Depression and obesity: a meta-analysis of community-based studies. Psychiatry Res 2010, 178:230-235.

111. Williams LJ, Pasco JA, Henry MJ, Jacka FN, Dodd S, Nicholson GC, Kotowicz MA, Berk M: Lifetime psychiatric disorders and body composition: a population-based study. J Affect Disord 2009, 118:173-179.

112. Faith MS, Butryn M, Wadden TA, Fabricatore A, Nguyen AM, Heymsfield SB: Evidence for prospective associations among depression and obesity in population-based studies. Obes Rev 2011, 12:e438-453.
113. Luppino FS, de Wit LM, Bouvy PF, Stijnen T, Cuijpers P, Penninx BW, Zitman FG: Overweight, obesity, and depression: a systematic review and meta-analysis of longitudinal studies. Arch Gen Psychiatry 2010, 67:220-229

114. de Heredia FP, Gomez-Martinez S, Marcos A: Obesity, inflammation and the immune system. Proc Nutr Soc 2012, 71:332-338.

115. Arvidsson E, Viguerie N, Andersson I, Verdich C, Langin D, Arner P: Effects of different hypocaloric diets on protein secretion from adipose tissue of obese women. Diabetes 2004, 53:1966-1971.

116. Panagiotakos DB, Pitsavos C, Yannakoulia M, Chrysohoou C, Stefanadis C: The implication of obesity and central fat on markers of chronic inflammation: the ATTICA study. Atherosclerosis 2005, 183:308-315.

117. Miller GE, Freedland KE, Carney RM, Stetler CA, Banks WA: Pathways linking depression, adiposity, and inflammatory markers in healthy young adults. Brain Behav Immun 2003, 17:276-285.

118. Lasser K, Boyd JW, Woolhandler S, Himmelstein DU, McCormick D, Bor DH: Smoking and mental illness: a population-based prevalence study. JAMA 2000, 284:2606-2610.

119. Lawrence D, Mitrou F, Zubrick SR: Smoking and mental illness: results from population surveys in Australia and the United States. BMC Publ Health 2009, 9:285.

120. Pasco JA, Williams LJ, Jacka FN, Ng F, Henry MJ, Nicholson GC, Kotowicz MA, Berk M: Tobacco smoking as a risk factor for major depressive disorder: population-based study. Br J Psychiatry 2008, 193:322-326.

121. Boden JM, Fergusson DM, Horwood L: Cigarette smoking and depression: tests of causal linkages using a longitudinal birth cohort. Br J Psychiatry 2010, 196:440-446.

122. Chaiton MO, Cohen JE, O'Loughlin J, Rehm J: A systematic review of longitudinal studies on the association between depression and smoking in adolescents. BMC Publ Health 2009, 9:356.

123. Lyons M, Hitsman B, Xian H, Panizzon MS, Jerskey BA, Santangelo S, Grant MD, Rende R, Eisen S, Eaves L, Tsuang MT: A twin study of smoking, nicotine dependence, and major depression in men. Nicotine Tob Res 2008, 10:97-108.

124. Stedman RL: The chemical composition of tobacco and tobacco smoke. Chem Rev 1968, 68:153-207.

125. Arunachalam G, Sundar IK, Hwang JW, Yao H, Rahman I: Emphysema is associated with increased inflammation in lungs of atherosclerosis-prone mice by cigarette smoke: implications in comorbidities of COPD. J Inflamm (Lond) 2010, 7:34.

126. Virdis A, Giannarelli C, Neves MF, Taddei S, Ghiadoni L: Cigarette smoking and hypertension. Curr Pharm Des 2010, 16:2518-2525.

127. Tamimi A, Serdarevic D, Hanania NA: The effects of cigarette smoke on airway inflammation in asthma and COPD: therapeutic implications. Respir Med 2012, 106:319-328.

128. Yanbaeva DG, Dentener MA, Creutzberg EC, Wesseling G, Wouters EF: Systemic effects of smoking. Chest 2007, 131:1557-1566.

129. Nunes SO, Vargas HO, Brum J, Prado E, Vargas MM, de Castro MR, Dodd S, Berk M: A comparison of inflammatory markers in depressed and nondepressed smokers. Nicotine Tob Res 2012, 14:540-546.

130. Tuon T, Valvassori SS, Lopes-Borges J, Fries GR, Silva LA, Kapczinski F, Quevedo J, Pinho RA: Effects of moderate exercise on cigarette smoke exposure-induced hippocampal oxidative stress values and neurological behaviors in mice. Neurosci Lett 2010, 475:16-19.

131. Anbarasi K, Vani G, Balakrishna K, Devi CS: Effect of bacoside A on membrane-bound ATPases in the brain of rats exposed to cigarette smoke. J Biochem Mol Toxicol 2005, 19:59-65.

132. Thome GR, Spanevello RM, Mazzanti A, Fiorenza AM, Duarte MM, da Luz SC, Pereira ME, Morsch VM, Schetinger MR, Mazzanti CM: Vitamin E decreased the activity of acetylcholinesterase and level of lipid peroxidation in brain of rats exposed to aged and diluted sidestream smoke. Nicotine Tob Res 2011, 13:1210-1219.

133. Stangherlin EC, Luchese C, Ardais AP, Nogueira CW: Passive smoke exposure induces oxidative damage in brains of rat pups: protective role of diphenyl diselenide. Inhal Toxicol 2009, 21:868-874.

134. Luchese C, Pinton S, Nogueira CW: Brain and lungs of rats are differently affected by cigarette smoke exposure: antioxidant effect of an organoselenium compound. Pharmacol Res 2009, 59:194-201.

135. Anbarasi K, Vani G, Balakrishna K, Devi CS: Effect of bacoside A on brain antioxidant status in cigarette smoke exposed rats. Life Sci 2006, 78:1378-1384. 
136. Hilbert J, Mohsenin V: Adaptation of lung antioxidants to cigarette smoking in humans. Chest 1996, 110:916-920.

137. Baskaran S, Lakshmi S, Prasad PR: Effect of cigarette smoke on lipid peroxidation and antioxidant enzymes in albino rat. Indian J Exp Biol 1999, 37:1196-1200

138. Maes $M$, Kubera $M$, Leunis JC: The gut-brain barrier in major depression: intestinal mucosal dysfunction with an increased translocation of LPS from gram negative enterobacteria (leaky gut) plays a role in the inflammatory pathophysiology of depression. Neuro Endocrinol Lett 2008 , 29:117-124

139. Maes M, Kubera M, Leunis JC, Berk M, Geffard M, Bosmans E: In depression, bacterial translocation may drive inflammatory responses, oxidative and nitrosative stress (O\&NS), and autoimmune responses directed against O\&NS-damaged neoepitopes. Acta Psychiatr Scand 2013, 127:344-354.

140. Maes M, Kubera M, Leunis JC, Berk M: Increased IgA and IgM responses against gut commensals in chronic depression: further evidence for increased bacterial translocation or leaky gut. J Affect Disord 2012, 141:55-62.

141. Wiest R: Bacterial translocation. Bioscience Microflora 2005, 24:61-90.

142. Todar K: Todar's online textbook of bacteriology; 2012 [http://textbookofbacteriology.net/]

143. Feng L, Xia Y, Garcia GE, Hwang D, Wilson CB: Involvement of reactive oxygen intermediates in cyclooxygenase-2 expression induced by interleukin-1, tumor necrosis factor-alpha, and lipopolysaccharide. J Clin Invest 1995, 95:1669-1675.

144. Lin WN, Lin CC, Cheng HY, Yang CM: Regulation of cyclooxygenase-2 and cytosolic phospholipase A2 gene expression by lipopolysaccharide through the RNA-binding protein HuR: involvement of NADPH oxidase, reactive oxygen species and mitogen-activated protein kinases. $\mathrm{Br} J$ Pharmacol 2011, 163:1691-1706.

145. Check J, Byrd CL, Menio J, Rippe RA, Hines IN, Wheeler MD: Src kinase participates in LPS-induced activation of NADPH oxidase. Mol Immunol 2010, 47:756-762.

146. Pai K, Sodhi A: Effect of cisplatin, rIFN-Y, LPS and MDP on release of $\mathrm{H} 2 \mathrm{O} 2, \mathrm{O} 2-$ and lysozyme from human monocytes in vitro. Indian J Exp Biol 1991, 29:910-915.

147. Takada K, Ohno N, Yadomae T: Binding of lysozyme to lipopolysaccharide suppresses tumor necrosis factor production in vivo. Infect Immun 1994, 62:1171-1175.

148. Berg RD, Garlington AW: Translocation of certain indigenous bacteria from the gastrointestinal tract to the mesenteric lymph nodes and other organs in a gnotobiotic mouse model. Infect Immun 1979, 23:403-411.

149. Wiest R, Garcia-Tsao G: Bacterial translocation (BT) in cirrhosis. Hepatology 2005, 41:422-433.

150. Clark E, Hoare C, Tanianis-Hughes J, Carlson GL, Warhurst G: Interferon gamma induces translocation of commensal Escherichia coli across gut epithelial cells via a lipid raft-mediated process. Gastroenterology 2005, 128:1258-1267.

151. Chavez AM, Menconi MJ, Hodin RA, Fink MP: Cytokine-induced intestinal epithelial hyperpermeability: role of nitric oxide. Crit Care Med 1999, 27:2246-2251

152. Yang R, Han X, Uchiyama T, Watkins SK, Yaguchi A, Delude RL, Fink MP: IL-6 is essential for development of gut barrier dysfunction after hemorrhagic shock and resuscitation in mice. Am J Physiol Gastrointest Liver Physiol 2003, 285:G621-629.

153. Al-Sadi RM, Ma TY: IL-1beta causes an increase in intestinal epithelial tight junction permeability. J Immunol 2007, 178:4641-4649.

154. Ye D, Ma I, Ma TY: Molecular mechanism of tumor necrosis factor-alpha modulation of intestinal epithelial tight junction barrier. Am J Physiol Gastrointest Liver Physio/ 2006, 290:G496-504.

155. Maes M, Mihaylova I, Kubera M, Leunis JC, Geffard M: IgM-mediated autoimmune responses directed against multiple neoepitopes in depression: new pathways that underpin the inflammatory and neuroprogressive pathophysiology. J Affect Disord 2011, 135:414-418.

156. Garate I, Garcia-Bueno B, Madrigal JL, Caso JR, Alou L, Gomez-Lus ML, Mico JA, Leza JC: Stress-induced neuroinflammation: role of the Toll-like receptor-4 pathway. Biol Psychiatry 2013, 73:32-43.

157. Johansson SG, Bieber T, Dahl R, Friedmann PS, Lanier BQ, Lockey RF, Motala C, Ortega Martell JA, Platts-Mills TA, Ring J, Thien F, van Cauwenberge $P$, Williams HC: Revised nomenclature for allergy for global use: report of the nomenclature review committee of the world allergy organization, October 2003. J Allergy Clin Immunol 2004, 113:832-836.

158. Jarvis $D$, Burney $P$ : $A B C$ of allergies. The epidemiology of allergic disease. BMJ 1998, 316:607-610.

159. Asher MI, Montefort S, Bjorksten B, Lai CK, Strachan DP, Weiland SK, Williams $\mathrm{H}$ : Worldwide time trends in the prevalence of symptoms of asthma, allergic rhinoconjunctivitis, and eczema in childhood: ISAAC Phases One and Three repeat multicountry cross-sectional surveys. Lancet 2006, 368:733-743.

160. Hashiro M, Okumura M: Anxiety, depression and psychosomatic symptoms in patients with atopic dermatitis: comparison with normal controls and among groups of different degrees of severity. J Dermatol Sci 1997, 14:63-67.

161. Cuffel B, Wamboldt M, Borish L, Kennedy S, Crystal-Peters J: Economic consequences of comorbid depression, anxiety, and allergic rhinitis. Psychosomatics 1999, 40:491-496.

162. Afari N, Schmaling K, Barnhart S, Buchwald D: Psychiatric comorbidity and functional status in adult patients with asthma. J Clin Psychol Med Settings 2001, 8:245-252

163. Mizara A, Papadopoulos L, McBride SR: Core beliefs and psychological distress in patients with psoriasis and atopic eczema attending secondary care: the role of schemas in chronic skin disease. $\mathrm{Br} J$ Dermatol 2012, 166:986-993.

164. Hurwitz EL, Morgenstern H: Cross-sectional associations of asthma, hay fever, and other allergies with major depression and low-back pain among adults aged 20-39 years in the United States. Am J Epidemiol 1999, 150:1107-1116

165. Timonen M, Jokelainen J, Hakko H, Silvennoinen-Kassinen S, Meyer-Rochow VB, Herva A, Rasanen P: Atopy and depression: results from the Northern Finland 1966 Birth Cohort Study. Mol Psychiatry 2003, 8:738-744.

166. Klokk M, Gotestam KG, Mykletun A: Factors accounting for the association between anxiety and depression, and eczema: the Hordaland health study (HUSK). BMC Dermatol 2010, 10:3.

167. Yang YW, Tseng KC, Chen YH, Yang JY: Associations among eczema, asthma, serum immunoglobulin $\mathrm{E}$ and depression in adults: a population-based study. Allergy 2010, 65:801-802.

168. Gunn JM, Ayton DR, Densley K, Pallant JF, Chondros P, Herrman HE, Dowrick CF: The association between chronic illness, multimorbidity and depressive symptoms in an Australian primary care cohort. Soc Psychiatry Psychiatr Epidemiol 2012, 47:175-184.

169. Prussin C, Metcalfe DD: 4. IgE, mast cells, basophils, and eosinophils. J Allergy Clin Immunol 2003, 111:S486-494.

170. Metcalfe DD, Baram D, Mekori YA: Mast cells. Physiol Rev 1997 77:1033-1079

171. Highfield J: Diagnosis and classification of periodontal disease. Aust Dent J 2009, 54:S11-26.

172. Eke PI, Dye BA, Wei L, Thornton-Evans GO, Genco RJ, CDC Periodontal Disease Surveillance workgroup: James Beck (University of North Carolina, Chapel Hill, USA), Gordon Douglass (Past President, American Academy of Periodontology), Roy Page (University of Washington): Prevalence of periodontitis in adults in the United States: 2009 and 2010. J Dent Res 2012, 91:914-920.

173. Dumitrescu AL, Kawamura M: Involvement of psychosocial factors in the association of obesity with periodontitis. J Oral Sci 2010, 52:115-124.

174. Monteiro da Silva AM, Oakley DA, Newman HN, Nohl FS, Lloyd HM: Psychosocial factors and adult onset rapidly progressive periodontitis. J Clin Periodontol 1996, 23:789-794.

175. Peruzzo DC, Benatti BB, Ambrosano GM, Nogueira-Filho GR, Sallum EA Casati MZ, Nociti FH Jr: A systematic review of stress and psychological factors as possible risk factors for periodontal disease. J Periodontol 2007, 78:1491-1504

176. Adeniyi AA, Ola BA, Edeh CE, Ogunbanjo BO, Adewuya AO: Dental status of patients with mental disorders in a Nigerian teaching hospital: a preliminary survey. Spec Care Dentist 2011, 31:134-137.

177. Okoro CA, Strine TW, Eke PI, Dhingra SS, Balluz LS: The association between depression and anxiety and use of oral health services and tooth loss. Community Dent Oral Epidemiol 2012, 40:134-144.

178. Mendes DC, Silva TF, de Barros LO, de Oliveira MV, Vieira LT, Haikal DS, Guimaraes AL, De Paula AM: Analysis of the normative conditions of oral health, depression and serotonin-transporter-linked promoter 
region polymorphisms in an elderly population. Geriatr Gerontol Int 2013, 13:98-106.

179. Socransky SS, Haffajee AD: Periodontal microbial ecology. Periodontol 2005, 38:135-187.

180. Page RC, Schroeder HE: Pathogenesis of inflammatory periodontal disease. A summary of current work. Lab Invest 1976, 34:235-249.

181. Amar S, Gokce N, Morgan S, Loukideli M, Van Dyke TE, Vita JA: Periodontal disease is associated with brachial artery endothelial dysfunction and systemic inflammation. Arterioscler Thromb Vasc Biol 2003, 23:1245-1249.

182. Kinane DF, Lowe GD: How periodontal disease may contribute to cardiovascular disease. Periodontol 2000, 23:121-126.

183. Saremi A, Nelson RG, Tulloch-Reid M, Hanson RL, Sievers ML, Taylor GW, Shlossman M, Bennett PH, Genco R, Knowler WC: Periodontal disease and mortality in type 2 diabetes. Diabetes Care 2005, 28:27-32.

184. Humphrey LL, Fu R, Buckley DI, Freeman M, Helfand M: Periodontal disease and coronary heart disease incidence: a systematic review and metaanalysis. J Gen Intern Med 2008, 23:2079-2086.

185. Hasturk H, Kantarci A, Van Dyke TE: Oral inflammatory diseases and systemic inflammation: role of the macrophage. Front Immunol 2012, 3:118.

186. Ara T, Kurata K, Hirai K, Uchihashi T, Uematsu T, Imamura Y, Furusawa K, Kurihara S, Wang PL: Human gingival fibroblasts are critical in sustaining inflammation in periodontal disease. J Periodontal Res 2009, 44:21-27.

187. Van Dyke TE: The management of inflammation in periodontal disease. J Periodontol 2008, 79:1601-1608.

188. Van Dyke TE: Resolution of inflammation-unraveling mechanistic links between periodontitis and cardiovascular disease. J Dent 2009, 37:S582-583.

189. Kronfol Z, Remick DG: Cytokines and the brain: implications for clinical psychiatry. Am J Psychiatry 2000, 157:683-694.

190. Kamer AR, Dasanayake AP, Craig RG, Glodzik-Sobanska L, Bry M, de Leon MJ: Alzheimer's disease and peripheral infections: the possible contribution from periodontal infections, model and hypothesis. J Alzheimers Dis 2008, 13:437-449

191. Savage VM, West GB: A quantitative, theoretical framework for understanding mammalian sleep. Proc Natl Acad Sci USA 2007, 104:1051-1056.

192. Kripke DF, Garfinkel L, Wingard D, Klauber MR, Marler MR: Mortality associated with sleep duration and insomnia. Arch Gen Psychiatry 2002, 59:137-138

193. Zisapel N: Sleep and sleep disturbances: biological basis and clinical implications. Cell Mol Life Sci 2007, 64:1174-1186.

194. Fanzen P, Buysse D: Sleep disturbances and depression: risk relationships for subsequent depression and therapeutic implications. Dialogues Clin Neurosci 2008, 10:473-481.

195. Bower B, Bylsma LM, Morris BH, Rottenberg J: Poor reported sleep quality predicts low positive affect in daily life among healthy and mooddisordered persons. J Sleep Res 2010, 19:323-332.

196. Turek F: Insomnia and depression: if it looks and walks like a duck. Sleep Res Online 2005, 28:1457-1464.

197. Peterson MJ, Benca RM: Sleep in mood disorders. Psychiatr Clin North Am 2006, 29:1009-1032. Abstract ix

198. Kaneita Y, Ohida T, Uchiyama M, Takemura S, Kawahara K, Yokoyama E, Miyake T, Harano S, Suzuki K, Yagi Y, Kaneko A, Tsutsui T, Akashiba T: Excessive daytime sleepiness among the Japanese general population. J Epidemiol 2005, 15:1-8.

199. Riemann D, Voderholzer U: Primary insomnia: a risk factor to develop depression? J Affect Disord 2003, 76:255-259.

200. Pigeon WR, Hegel M, Unutzer J, Fan MY, Sateia MJ, Lyness JM, Phillips C, Perlis ML: Is insomnia a perpetuating factor for late-life depression in the IMPACT cohort? Sleep 2008, 31:481-488.

201. McClung CA: Circadian genes, rhythms and the biology of mood disorders. Pharmacol Ther 2007, 114:222-232.

202. Irwin M, McClintick J, Costlow C, Fortner M, White J, Gillin JC: Partial night sleep deprivation reduces natural killer and cellular immune responses in humans. FASEB J 1996, 10:643-653.

203. Simpson N, Dinges DF: Sleep and inflammation. Nutr Rev 2007, 65:S244-252.

204. Shearer WT, Reuben JM, Mullington JM, Price NJ, Lee BN, Smith EO, Szuba MP, Van Dongen HP, Dinges DF: Soluble TNF-alpha receptor 1 and IL-6 plasma levels in humans subjected to the sleep deprivation model of spaceflight. J Allergy Clin Immunol 2001, 107:165-170.
205. Haack M, Sanchez E, Mullington JM: Elevated inflammatory markers in response to prolonged sleep restriction are associated with increased pain experience in healthy volunteers. Sleep 2007, 30:1145-1152.

206. Strike PC, Steptoe A: Systematic review of mental stress-induced myocardial ischaemia. Eur Heart J 2003, 24:690-703.

207. Wolk R, Somers VK: Sleep and the metabolic syndrome. Exp Physiol 2007 92:67-78

208. Vgontzas AN, Zoumakis M, Bixler EO, Lin HM, Prolo P, Vela-Bueno A, Kales A, Chrousos GP: Impaired nighttime sleep in healthy old versus young adults is associated with elevated plasma interleukin- 6 and cortisol levels: physiologic and therapeutic implications. J Clin Endocrinol Metab 2003, 88:2087-2095.

209. Taheri S, Austin D, Lin L, Nieto FJ, Young T, Mignot E: Correlates of serum C-reactive protein (CRP)-no association with sleep duration or sleep disordered breathing. Sleep 2007, 30:991-996.

210. Patel SR, Zhu X, Storfer-Isser A, Mehra R, Jenny NS, Tracy R, Redline S: Sleep duration and biomarkers of inflammation. Sleep 2009, 32:200-204.

211. Speigelhalder K, Scholtes C, Riemann D: The association between insomnia and cardiovascular disease. Nat Sci Sleep 2010, 2:71-78

212. Novati A, Roman V, Cetin T, Hagewoud R, den Boer JA, Luiten PG, Meerlo P: Chronically restricted sleep leads to depression-like changes in neurotransmitter receptor sensitivity and neuroendocrine stress reactivity in rats. Sleep 2008, 31:1579-1585.

213. Meerlo P, Koehl M, van der Borght K, Turek FW: Sleep restriction alters the hypothalamic-pituitary-adrenal response to stress. J Neuroendocrinol 2002, 14:397-402.

214. Krishnan V, Nestler EJ: The molecular neurobiology of depression. Nature 2008, 455:894-902

215. Dunn AJ, Swiergiel AH, de Beaurepaire R: Cytokines as mediators of depression: what can we learn from animal studies? Neurosci Biobehav Rev 2005, 29:891-909.

216. Chourbaji S, Urani A, Inta I, Sanchis-Segura C, Brandwein C, Zink M, Schwaninger M, Gass P: IL-6 knockout mice exhibit resistance to stressinduced development of depression-like behaviors. Neurobiol Dis 2006, 23:587-594.

217. Lucassen PJ, Meerlo P, Naylor AS, van Dam AM, Dayer AG, Fuchs E, Oomen CA, Czeh B: Regulation of adult neurogenesis by stress, sleep disruption, exercise and inflammation: implications for depression and antidepressant action. Eur Neuropsychopharmacol 2010, 20:1-17.

218. Sluzewska A, Rybakowski JK, Laciak M, Mackiewicz A, Sobieska M, Wiktorowicz K: Interleukin-6 serum levels in depressed patients before and after treatment with fluoxetine. Ann N Y Acad Sci 1995, 762:474-476.

219. Pasco JA, Henry MJ, Nicholson GC, Sanders KM, Kotowicz MA: Vitamin D status of women in the Geelong osteoporosis study: association with diet and casual exposure to sunlight. Med J Aust 2001, 175:401-405.

220. Nowson CA, McGrath JJ, Ebeling PR, Haikerwal A, Daly RM, Sanders KM, Seibel MJ, Mason RS: Vitamin D and health in adults in Australia and New Zealand: a position statement. Med J Aust 2012, 196:686-687.

221. Eyles D, Burne T, McGrath J: Vitamin D in fetal brain development. Semin Cell Dev Biol 2011, 22:629-636.

222. Lansdowne AT, Provost SC: Vitamin D3 enhances mood in healthy subjects during winter. Psychopharmacology (Berl) 1998, 135:319-323.

223. Sanders KM, Stuart AL, Williamson EJ, Jacka FN, Dodd S, Nicholson G, Berk M: Annual high-dose vitamin D3 and mental well-being: randomised controlled trial. Br J Psychiatry 2011, 198:357-364.

224. Battersby AJ, Kampmann B, Burl S: Vitamin D in early childhood and the effect on immunity to mycobacterium tuberculosis. Clin Dev Immunol 2012, 2012:430972.

225. Beilfuss J, Berg V, Sneve M, Jorde R, Kamycheva E: Effects of a 1-year supplementation with cholecalciferol on interleukin-6, tumor necrosis factor-alpha and insulin resistance in overweight and obese subjects. Cytokine 2012, 60:870-874.

226. Grossmann RE, Zughaier SM, Liu S, Lyles RH, Tangpricha V: Impact of vitamin $D$ supplementation on markers of inflammation in adults with cystic fibrosis hospitalized for a pulmonary exacerbation. Eur J Clin Nutr 2012, 66:1072-1074.

227. Faridar A, Eskandari G, Sahraian MA, Minagar A, Azimi A: Vitamin D and multiple sclerosis: a critical review and recommendations on treatment. Acta Neurol Belg 2012, 112:327-333.

228. Jain S, Manna P, Micinski D, Lieblong B, Kahlon G, Morehead L, Hoeldtke R, Bass PF, Levine SN: In African American type 2 diabetic patients, is 
vitamin D deficiency associated with lower blood levels of $\mathrm{H} 2 \mathrm{~S}$ and cAMP, and elevated oxidative stress? Antioxid Redox Signal 2013, 18:1154-1158

229. Hart PH: Vitamin D supplementation, moderate sun exposure, and control of immune diseases. Discov Med 2012, 13:397-404.

230. Maes M, Bosmans E, Calabrese J, Smith R, Meltzer HY: Interleukin-2 and interleukin-6 in schizophrenia and mania: effects of neuroleptics and mood stabilizers. J Psychiatr Res 1995, 29:141-152.

231. Maes M, Delange J, Ranjan R, Meltzer HY, Desnyder R, Cooremans W, Scharpe S: Acute phase proteins in schizophrenia, mania and major depression: modulation by psychotropic drugs. Psychiatry Res 1997, 66:1-11.

232. Rapaport MH: Immune parameters in euthymic bipolar patients and normal volunteers. J Affect Disord 1994, 32:149-156.

233. Modabbernia A, Taslimi S, Brietzke E, Ashrafi M: Cytokine alterations in bipolar disorder: a meta-analysis of 30 studies. Biol Psychiatry 2013 [Epub ahead of print.].

234. Miller BJ, Buckley P, Seabolt W, Mellor A, Kirkpatrick B: Meta-analysis of cytokine alterations in schizophrenia: clinical status and antipsychotic effects. Biol Psychiatry 2011, 70:663-671.

235. Spivak B, Shohat B, Mester R, Avraham S, Gil-Ad I, Bleich A, Valevski A, Weizman A: Elevated levels of serum interleukin-1 beta in combatrelated posttraumatic stress disorder. Biol Psychiatry 1997, 42:345-348.

236. Maes M, Lin AH, Delmeire L, Van Gastel A, Kenis G, De Jongh R, Bosmans E: Elevated serum interleukin-6 (IL-6) and IL-6 receptor concentrations in posttraumatic stress disorder following accidental man-made traumatic events. Biol Psychiatry 1999, 45:833-839.

237. Gill J, Luckenbaugh D, Charney D, Vythilingam M: Sustained elevation of serum interleukin- 6 and relative insensitivity to hydrocortisone differentiates posttraumatic stress disorder with and without depression. Biol Psychiatry 2010, 68:999-1006.

238. Gola H, Engler H, Sommershof A, Adenauer H, Kolassa S, Schedlowski M, Groettrup M, Elbert T, Kolassa IT: Posttraumatic stress disorder is associated with an enhanced spontaneous production of proinflammatory cytokines by peripheral blood mononuclear cells. BMC Psychiatry 2013, 13:40.

239. Anderson G, Maes M: Schizophrenia: linking prenatal infection to cytokines, the tryptophan catabolite (TRYCAT) pathway, NMDA receptor hypofunction, neurodevelopment and neuroprogression. Prog Neuropsychopharmacol Biol Psychiatry 2013, 42:5-19.

240. de Leon J, Diaz FJ: A meta-analysis of worldwide studies demonstrates an association between schizophrenia and tobacco smoking behaviors. Schizophr Res 2005, 76:135-157.

241. Citrome L, Vreeland B: Schizophrenia, obesity, and antipsychotic medications: what can we do? Postgrad Med 2008, 120:18-33.

242. Chen YH, Lee HC, Lin HC: Prevalence and risk of atopic disorders among schizophrenia patients: a nationwide population based study. Schizophr Res 2009, 108:191-196.

243. Bersani FS, lannitelli A, Pacitti F, Bersani G: Sleep and biorythm disturbances in schizophrenia, mood and anxiety disorders: a review. Riv Psichiatr 2012, 47:365-375.

244. Arnaiz A, Zumarraga M, Diez-Altuna I, Uriarte JJ, Moro J, Perez-Ansorena MA: Oral health and the symptoms of schizophrenia. Psychiatry Res 2010, 188:24-28.

245. Eltas A, Kartalci S, Eltas S, Dundar S, Uslu M: An assessment of periodontal health in patients with schizophrenia and taking antipsychotic medication. Int J Dent Hyg 2013, 11:78-83.

246. Thorndike FP, Wernicke R, Pearlman MY, Haaga DA: Nicotine dependence, PTSD symptoms, and depression proneness among male and female smokers. Addict Behav 2006, 31:223-231.

247. Heppner PS, Lohr JB, Kash TP, Jin H, Wang H, Baker DG: Metabolic syndrome: relative risk associated with post-traumatic stress disorder (PTSD) severity and antipsychotic medication use. Psychosomatics 2012, 53:550-558.

248. Muhvic-Urek M, Uhac I, Vuksic-Mihaljevic Z, Leovic D, Blecic N, Kovac Z: Oral health status in war veterans with post-traumatic stress disorder. $J$ Oral Rehabil 2007, 34:1-8.

249. Gupta MA: Review of somatic symptoms in post-traumatic stress disorder. Int Rev Psychiatry 2013, 25:86-99.

250. Stafford L, Berk M: The use of statins after a cardiac intervention is associated with reduced risk of subsequent depression: proof of concept for the inflammatory and oxidative hypotheses of depression? J Clin Psychiatry 2011, 72:1229-1235.

251. Pasco JA, Jacka FN, Williams LJ, Henry MJ, Nicholson GC, Kotowicz MA, Berk M: Clinical implications of the cytokine hypothesis of depression: the association between use of statins and aspirin and the risk of major depression. Psychother Psychosom 2010, 79:323-325.

doi:10.1186/1741-7015-11-200

Cite this article as: Berk et al: So depression is an inflammatory disease, but where does the inflammation come from?. BMC Medicine 2013 11:200.

\section{Submit your next manuscript to BioMed Central and take full advantage of:}

- Convenient online submission

- Thorough peer review

- No space constraints or color figure charges

- Immediate publication on acceptance

- Inclusion in PubMed, CAS, Scopus and Google Scholar

- Research which is freely available for redistribution 